\title{
Editorial
}

\section{Journal of the South African Sports Medicine Association}

\section{Olympic Issue}

The growth and international acceptance of sports medicine owes much to the modern Olympic Games. ${ }^{1}$ The first significant event was the creation of the International Olympic Committee(IOC) Medical Committee in 1964 with the express responsibility of controlling drug use in Olympic competition. The work of that committee focused global attention on our profession and its role in contemporary issues in international sport.

More recently that committee has been responsible for selecting the first recipient(s) of the IOC Olympic Prize which honours scientists with a lifetime of exceptional achievement in the sports sciences. This award, perhaps the equivalent of a Nobel Prize in the Sports Sciences, will be bestowed on Professors Ralph Paffenbarger and Jerry Morris prior to the start of this year's Atlanta Olympic Games, and will further enhance the stature of the profession before a massive global audience. Professor Ralph Paffenbarger has been a friend of South African sports medicine for many years; he spoke at our International Congress in Cape Town in 1989 and has completed both the Two Oceans and Comrades Marathons, the latter when he was well into his sixties. The work of these two visionary giants has established that physical inactivity is a major factor for coronary heart disease and also contributes to the aetiology of a number of other diseases including hypertension, diabetes and cancer of the large bowel. It is appropriate that the Olympian life work of these two great gentlemen of the sports sciences should be appropriately recognised; their work proves the value of physical activity and provides the intellectual anchor which our professional credibility is secured.

The second Olympic event that has helped in the growth of the sports sciences was the quite dramatic rise to dominance of the Eastern German Democratic Republic(GDR), in Olympic competition. During the 1968 Olympic Games, the first Games in which the GDR competed as a team separate from West Germany, their athletes won 25 medals. In the 1988 Olympic Games, athletes from that country won 102 medals, one more than the total medal count for athletes from the United States, a country with a population almost tenfold larger than that of the GDR. Other nations perceiving that this success resulted from a more "scientific" and professional approach to sport in the GDR, began to investigate ways in which science could be profitably applied for the enhancement of human sporting performance. Of the Commonwealth Countries, Australia and perhaps to a lesser extent Canada, have taken the lead in these developments.

The third important factor was the holding of the 1968 Olympic Games at Mexico City at an altitude of $2270 \mathrm{~m}$. Never before had the Olympic Games been held in a city so high above sea-level: This single event first exposed, on an international scale, the very embarrassing inadequacies in our knowledge of some quite basic issues in the applied sports sciences. For at that time, the real effects of medium altitude on athletic performance were simply not known. Nor had the potential health risks associated with holing Olympic competition at altitude been studied. Many of the great exercise scientists of the modern era first cut their scientific teeth in the research of that question. I would suggest that analysis will show that it was after 1968 and the scientific stimulus provided by those Olympic Games, that our profession really took off. Mindful of the importance of Olynupic Games for our profession, it is appropriate that this issue of our journal should be devoted to sports medical issues of special relevance to the Olympic Games.

It is often useful to begin in the past. To set the scene, Dr Floris van der Merwe reviews some of the great moments of South African achievements in Olympic track and field competition. He reminds us that only 5 South African athletes have won medals in the Olympic track and field competition. Only one of those gold medals has been won since the Second World War, suggesting that our international standing in international competition has fallen. He points out that politics robbed South Africa of some of its greatest recent track and field athletes like Sydney Mare, Mark Plaațies and Freddie Fredericks, world-class athletes who might well have won Olympic medals for South Africa in the more recent Olympic Games.

If political factors, since corrected, restricted our Olympic potential in the past, I would suggest that the future success of our Olympic athletes will require that they receive the best that our profession can offer, including our capacity for innovation. For analysis of the great Olympic athletes reveals that most were in the forefront of innovative training methods. The great Finnish distance runners who dominated the early Olympic Games owed their success to the introduction of distance training during the winter months. ${ }^{2}$ These methods were refined by Paavo Nurmi, one of the first runners to include regular speed training in his preparation. Nurmi is considered to be the greatest Olympian of all time. ${ }^{3}$ Emil Zatopck refined the techniques of speed training, winning a total of 4 gold medals at the 
1948 and 1952 Olympics including the $42 \mathrm{~km}$ marathon which he considered the "most boring race" he had ever nu!! The next great Finnish nuuler, Lasse Viren, won 4 gold mélals in 1972 and 1976 with this introduction of the concept of racing infrequently and "peaking" only for the Olympic Gannes, a technicfuc also followed by Frauls Shorter, gold and silver medallist in the 1972 and 1976 Olympic Marathons respectively. What innovatire training techuiques will our athletes have followed in their preparation for the 1996 Olynupic Games?

The articles by Drs John Hawley and Helgo Schomer and Ms. Elske Schabort review the phrsiological and psychological factors that contribute to the success in intemational sporting competition. Hawley and Schabont revicw the progression of world ruming records and ask whether there are iclentifiable physiological changes that might explain the progressive pattern of improvement in these records. They conclude that the maximum oxygen consumption of the modern world record holder is not likely higher than that of earlier record holkers. Rather the rariable that has changed, is the specific cndurance which is the capacity to sustain a high percentage of the maximum oxygen consumption for longer during competition. Factors that could explain this change inclucle improved running tracks, commercialism, professionalism, more numerous conpetitive opportunities, improved nutrition, and perhaps the use of pharmacological agents in training.

In his cletailed yet practical article, Dr Helgo Schomer review's the psychological preparation for Olympic competition. He begins with the premise that there are no physical clifferences between the very best athletes in any sport. Rather the winner is the athlete who is mentally the strongest on the day of competition. Schomer identifies the four important psycloological factors determining success and describes the psychological skills training programnes that are crucial for devcloping those skills. He suggests that sporting success comes when these techniques become second nature. He provides appropriate guidelines for psychological training and concludes that lifelong practice is required to perfect these mental skills. Of course, the value of these mental skills extends beyond the Olympic arena, to all levels, of sport and to daily life.

But the major Olympic challenge remains the promotion of fair competition by eliminating the use of performance enlancing drugs including the anabolic steroids, erythropoeitin and growth hormone. Di George van Dugteren of the National Olympic Committee of South Africa (NOCSA) has prepared an Anti-Doping policy on behalf of NOCSA and the South African Institute for Drugfree sport. This policy is reproduced here, as is the latest(1996) edition of the IOC list of banned drugs. This is crucial information for all who treat or advise our Olympic athlctes.

Another important source of this information, the MIMS book, Permitted and Banned Drugs in Sport - has recently been published but is perhaps not as wirlely known as might be hoped. The additional valuc of that publication is that it provides lists of banncel and permitted drugs according to their trade names. This allows the athlete and his or her nicdical consultant to be absolutely ectain of the status of any medication availal)le in South Africa. The book is availal)le only from the MIMS office (PO Box 2059, Pretoria, 0001: phone number 0123485010$)$.

The issuc also includes onc of the most thought.provoking articles on clrug control in sport that I have read. In his article Australian sports physician Dr Manucl Cusi poses three differcnt sccinarios that might be encountered by any doctor treating athletes. The first involves the prescription of anabolic steroids or other banned drugs by doctors appointed in an official capacity to sporting teams. Cusi argues that such doctors mar not prescrile banner substances to team members. The second scenario is perhaps nore common and inrolves the prescription of anabolic steroids for athletes involved in non competitive sports. Again the ethical position taken by Cusi is that such drugs should not be prescribed by docetors and the reasons for this position are carefully argucd. His thirel scenario presents the problem of prescribing medication for the treatment of legitimate medical condition in an athlete who competes in a sport in which that specific drug is banned. His conclusion may seem surprising. Perhaps his most challenging statement is that his three scenarios "indicate that medical practice is nore complex than the IOC's anti-doping rationale adnits." Long may this clebate continue.

Spccial thanks are due to all our anthors for their diligence in sharing their knowledge and specially to our Australian colleagues, Dr Cusi and Dr Peter Brukner, former clitor of SportHealth, who have given their permission for the use of $\mathrm{Dr}^{\text {. }}$ Cusi's article.

We wish our athletes and their medical support team all possible success in the Atlanta Olympic Games and hope that this issue of our joumal will portend a farourable change in South Africa's recent achicvements in Olympic competition.

\section{Editor \\ Professor Tin Noakes}

MRC/UCT Bioenergetics of Exercise Research Unit and Liberty Life Chair of Exercise and Sports Science, Sports Science institute of South Africa. Boundary Road. Newlands, 7700, South Africa.

\section{REFERENCES}

1. Noakes TD. The Olympic Games and Sports Medicine. British Journal of Sports Medicine.

2. Noakes TD. Lore of Running. Oxford University Press. 1992.

3. Johnson WO. Who is the greatest? Time Magazinc, June 24th, 1996,pp68-89. 


\section{THE SOITH IFRIC IN,JOIRIII, OF SPOR'TS MEDICINE}

VOLUME 3

NI MBBER 2 JULY 1996

Editor

Prof TD Noakes

Dr MP Schwellnus

Editorial Board

Dr M E Moolla

Dr P a le Jager

Dr J Skowno

Dr P Schwartz

Prof R Strelch

Dr C de Ridder

Prof B C Andrews

DrE W Derman

Mr R H Farman

Prof M Mars

DrC A Noble

International Advisory Board

Lyle J Micheli

Associate Clinical Professor of

Orthopacdic Surgery

Boston, USA

Chester $R$ Kyle

Research Dircctor, Sports

Equipment Rescarch Associates California, ISA

Prof HC Wildor Hollmann

Präsident des Deutschen

Sportärztebundes

Koln, West Germany

Howard J Green

Professor, Department of

Kinesiology

Ontario, Canada

George A Brooks

Professor, Department of

Pliysical Education

California, USA

Neil F Gordon

Director, Exercise Physiology

Texas, USA

Edmund $R$ Burke

Associate Professor, Biology

Department, University of

Colorado

Colorado, USA

Graham N Smith

Physiologist

Glasgow, Scotland

\section{CONTENTS}

\section{Editorial}

TD Noakes

Onthullings oor Suid-Afrika se goue medaljes in atletiek

FJG Van der Merwe

The limits to human performance:

A physiological perspective

$J A$ Hawley

EJ Schabort

Psychological preparation for olympic

athletes

$H$ Schomer

NOCSA - anti-doping policy

G Ruijsch van Dugteren

South African Institute for drug-free sport

Doping and clinical practice: Ethical Perspectives

\section{The Editor,}

The South African Jounial of Sports Medicine PO Bo.x 115, Newlands 7725

PRODUCTION

Andrew Thomas

PUBLISHING

Glenbarr Publishers ca

Private Bag X14

Parklands 2196

Tcl: (011) $442-9759$

Fax: (011) 880.7898
ADVERTISING

Marike de Waal/Andrew Thomas REPRODUCTION

Output Reproductions

PRINTING

Hortors

\section{Reparil-Gel \\ Relieves muscular pain}

The views expressed in individual articles are the personal views of the Authors and are not necessarily shared by the Editors, the Advertisers or the Publishers. No articles may be reproduced without the written consent of the Publishers. 


\title{
ONTHULLINGS OOR SUTD-AFRIKA SE GOUE MEDALJES IN ATLETIEK
}

\author{
FJG van der Merwe, D Phil, Departement Menslike Bewegingskunde, Universiteit van Stellenbosch
}

\begin{abstract}
South African sport is back in the international arena and is doing quite well lately. This year is the centenary of the modern Olympic movement. South Africa is hoping to win a gold medal in the track and field athletics. So far only five South African athletes have succeeded in winning this much sought-after trophy. They were Reggie Walker (1908), Kenneth McArthur (1912), Bevil Rudd (1920), Sid Atkinson (1928) and Esther Brand (1952). With the exception of Esther Brand, all of South Africa's gold medals were won before the Second World War. Already in 1947 Dr Ernst Jokl predicted that the African athletes would follow in the footsteps of the Scandinavian achievements. Unfortunately the SAAAU put a colour ban on athletics as early as 1931. This, and the later apartheid policy, deprived many non-white athletes of the opportunity to win a gold medal in the Olympic Games.
\end{abstract}

Keywords: South Africa, Olympic Games Track and field athletics.

\section{Inleiding}

Die Springbokke is die wereld se rugbykampioen, die Bafana Bafana is Afrika se solkkerkampioen en die Proteas het hul voete in internasionale krieket gevind en gaan van krag tot krag. Die lang droogte wat die beleid van sportisolasie jeens Suid-Afrika meegebring het, is iets van die verlede. Vanjaar word die moderne Olimpiese Spelebeweging 100 jaar oud en Suid-Afrika neem vir die tweede keer sedert 1960 daaraan deel. Baron Pierre de Coubertin se Olimpiïsme ${ }^{1}$ wat behels dat sport eerder karakter moet kweek as rekords najaag, was nog altyd net 'n droom. Wanneer daar van Olimpiese helde gepraat word, is die silwer- en bronsmedaljewenners vall minder belang - die held(in) bly nou eenmaal die persoon wat die hoogste plek op die rostrum ingeneem het. Hierdie prestasie het StudAfrika slegs tussen 1908 en 1952 te beurt geval.

Dit will tans voorkom asof Stud-Afrika 'n goeie kans op 'n goue medalje in Atlanta in atletiek sal hê. In retrospeksie het Suid-Afrika van 1908 tot 1960 en in 1992 slegs vyf atletiekprestasies opgelewer wat goed genoeg was om 'n goue medalje te verower. Daar sal in die onderhawige artikel kortliks gemotiveer word waarom hul prestasies so uitsonderlik was.

\section{Metode}

In 'n studie van dergelike aard word die historieswetenskaplike metode gebruik met die klem op primêre bronne ten einde die verlede so noukeurig en volledig moontlik te rekonstrueer. Die primêre bronne was onder andere die notules van die Suid-Afrikaanse Olimpiese en Rylspelevereniging, notules van vergaderings van die Internasionale Olimpiese Komitee, amptelike verslae van spanbestutrders en afrigters, amptelike verslae van die Organiserende Komitees van elke Spele, en onderhoude en korrespondensie met deelnemers en ander ooggetuies.

Nadat die bronne aan interne en eksterne kritiek onderwerp was, is die inligting tot 'n sintese gevoer.

\section{Resultate en bespreking}

Alhoewel Suid-Afrikaners (waaronder twee Zoeloes) al in 1904 in St. Louis aan die Olimpiese Spele deelgeneem het, was die eerste amptelike deelname eers in 1908 toe die Spele in Ionden plaasgevind het. Die 19 jarige Reggie Walker van Durban het daar 'n einde aan die Amerikaanse oorheersing in die 100 meter gemaak. Alhoewel James Rector in sy uitdun 'n Olimpiese rekord van $10,8 \mathrm{sek}$. opgestel het, het Walker dit in die semi-finaal en in die finaal geëwenaar om sodoende die Amerikaner in die finaal die loef af te steek.

Afgesien van die feit dat Walker Suid-Afrika se enigste Olimpiese naelloopkampioen is, is dit van akademiese belang om hier te let op 'n historiese wanvoorstelling wat met sy geval gepaard gaan. Sedert die Amptelike Verslag van die Londense Spele in 1909 gepubliseer het dat Walker nie oorsponldlik in die SuidAfrikaanse Olimpiese span opgeneem was nie, ${ }^{3}$ het hierdie fout herhaaldelik in verwante literatuur na vore gekom. Dit was eers toe die "verlore" notules van die Suid-Afrikaanse Amateuratletiekvereniging in die laat 1980 's opgespoor is, dat die volle waarheid ontbloot is. Dit was in werklikheid HT Phillips, ook 'n naelloper, wat eers later in die span opgeneem is nadat Pretorianers sy koste betaal het. Walker was van meet af aan in die span as sesde keuse."

In die daaropvolgende Spele, in Stocldholm 1912, was dit die marathonatlete se beurt om roem vir SuidAfrika te verwerf. Kennedy Kane McArthur en Christopher Gitsham het nie net eerste en tweede onderskeidelik geëindig nie, maar Stuid-Afrika was ook die laaste land wat so 'n dubbel prestasie in die marathon kon vermag.

'n Persoonlike onderhoud met HB Keartland," die Olimpiese atletiekafrigter van 1912, het aan die lig gebring dat daar veel meer agter "Kenneth" McArther en "Chris" Gitsham se prestasie skuil as wat die rekordboeke wil laat blyk. So byvoorbeeld was die Olimpiese marathon slegs die tweede dergelike nommer vir Gitsham. Keartland, wat die potensiaal in Gitsham raakgesien het, het hom oppad na Swede in Londen vir die Polytechnic-marathon ingeslaryf. Gitsham het sy vuurdoop met vlieënde vaandels geslaag deur tweede te eindig. Hierdie marathon het ook as proewe vir die Britse Olimpiese atlete gedien.

Keartland was dit ook eens dat Gitsham meer talent as die gesoute Kenneth McArthur gehad het. Die twee Springboklse het die tweede helfte van die wedloop oor $40,200 \mathrm{~km}$ saam in die voortou afgelê, maar volgens hom het Gitsham sy pas ingehou om vir sy spanmaat morele ondersteuning te gee. Vyf kilometer vanaf die stadion het Gitsham die roete verlaat om by 'n fontein 
water te gaan drink. Hy was onder die indruk dat McArtlı1r vir hom son wag, maar laasgenoende het in daardie tyd sowat 200 meter gevorder. Krampe het Gitsham toe genoodsaak om 'n lang ent te stap voordat hy sy spanmaat agterna kon sit." $\mathrm{Na}$ afloop van die wedloop het die saggeaarde Gitsham inderdaad beledig. ings na sy spanmaat geslinger ondat liy nie vir hom gewag het nie. ${ }^{7}$ McArthur se tyd was 2:36:54, ${ }^{*}$ en dié vau Gitsham, 2:37:52,0.*

Na die Eerste Wêreldoorlog is die Spclerecks in 1920 in Antwerpen liervat. Op hierdie Spele liet Bevil Gordon D'Urban Rudd dic enigste Suid-Afrikaner geword om 'n volledige stel Olimpiese medaljes te verower: Alloewel hy tén tyde van die Spele 'n Rlıodesstudent aan die Universiteit vau Oxford was, het hy in Springbolkkleure gehardloop en teen die verwagting in die Anerikaners onttroon on die gone medalje in die 400 meter te verower met 'n tyd vail 49,6 sek. Hy liet in dic finaal die uitgetrapte binnebaan geloot, maar desineteenstaande sy naaste teenstander met twee meter geklop. Lu die 800 meter het Rudd in die laaste pylval voorgeloop toe liy gestruikel en sy enlkel beseer het. Hy kon egter daarin slaag on steeds die bronsmedalje in te palm. Hy is in dic proses denr die Britse en Amerikaause kampioene geklop. Sy derde medalje was die silwer in die 4 x400 meter aflos."

In 1928, in Amsterdam, het Sidney James Montford Atkinson die enigste Suid-Afrikaner geword om die 110 meter lieklictitel te verower: ${ }^{10}$ Wat sy prestasie $110 \mathrm{~g}$ meer indrukwelkkend maak is die feit dat liy by dic vorige Spele, in Parys, die silwermedaljewenner in dieselfide nommer was. Hy liet in die finaal 'n 0,25 meter voorsprong geliad toe hy die laaste liekkie raakgesliop en effens gestruilkel het. Dit was genoeg vir sy Amerilkaanse teenstander (Daniel Kinsey) on hom na die lint te klop. Alloewel beide 'n tyd van 15,0 sek. aangeteken het, is Kinsey eerste geplaas. ${ }^{11}$

Vier jaar later liet Sid Atkinson die nommer in 14,8 selk. gewen. Met hierdie tyd het hy die ou Olimpiese rekord van 1920 geëwenaar. ${ }^{12}$ Dit was ook dieselfde tyd wat sy spanmaat, George C Weightman-Smitl, in die uitdume behaal het. Weightman-Smith, het in die semi-finaal egter' 'n n11we wêreld-en Olimpiese rekord van 14,6 sek. opgestel. In die finaal het hy die nitge. trapte binnebaan geloot, alhoewel dit vir die beamptes moontlik was onn die helklies sô op te stel dat die binnebaan nie gebruik hốf te geword het nie. Die niteincle van die saak was dat hy vyfde $(15,0$ selk.) en Sirl Atkinson cerste $(14,8$ sek.) geëindig het.

Ira Emery, 49 jaar laulk die sekretaris van die Suid. Afrikaanse Olimpiese Spelevereniging en bestuturder van verskeie Springbolsspanne na die Spcle, het in sy bock Springbolks of the Olympiad (1956) geskryf dat dit Atkinson was wat dic binnebaan geloot het en dat luulle op Weightman-Smith se aandrang bane geruil het. Atkinson sou toe in die vyfde in plaas van die binnebaan gehardloop het. Geen ander primêre bron ondersteum Enery se verliaal nic en die foto in die amptelike verslag van die Spele toon dat Atkinson in die derde baan geliardloop het. ${ }^{14}$ Snaar Viljoen liet as ooggetuic ook dic verhaal van Emery ontlen. ${ }^{15}$ Op '11 vraag waaron 11y nie oor die uitgetrapte binncbaan beswaar aangeteken het nie, het Weightinan-Smith verlslaar dat hy nooit klagtes op die sportveld sal opper nie. ${ }^{16}$
Suid-Afrika se laaste gone medalje in 'n Olinpiese atletieknommer (en die enigste denr' 11 vrone atleet) is in Helsinki in 1952 behaal toe die 28-jarige Esther (née van Heerden) Brand die loogspring vir vrone gewen het. Haar insluiting in die Olimpicse span lict net baic kritiels gepaád gegaan, maar liaar wenloogte vall 1,67 neter was goed genoeg on die wêreldrelrordhouer met 0,02 meter te klop. ${ }^{17}$ Die Olimpiese rekord op daardic tydstip was 1,68 meter. ${ }^{1+}$

Hierdie prestasie het 11 jaar nà haar wêreldrekordsprong as 17-jarige skooldogter op Coetzcnburg gekom. Tos, op 29 Maart 1941, het sy 'n hoogte van 1,65 meter behaal. Esther se rekord is egter nie destyds as 'n wêreldrekord erlken nie aangesien die rekordloogte van 1,67 meter toé agter die naam van Dora Ratjen van Duitsland gestaan het. In 1957 is Ratjen as 'n man ontblont en sy relkord is in 1960 op 'n vergadering van die IAAF in Rome nictig verklatar. Hermann Ratjen se verweer was dat liy in die oorlogsjare deur die Nazi's gedwing was on as 'n vion deel te neem ten einde roen en eer vir Duitse sport te verwerf. Met die skrapping van sy relord is Esther s'n eers 19 jaar later as wêreldrelrord crken."

\section{Samevalting}

'n Statistiese ontleding van Suid-Afrika se prestasies op die Olimpiese Spele van 1908 tot 1960 dui aan dat die atlete nâ die Tweede Wêreldoorlog nie so gocd soos vóór die oorlog gevaar het nie. Die enigste goeic na-oorlogse prestasie was in 1952 toe die 13 Springboliatlete twee medaljes ingepalin lict. In 1908 liet Siud-Afrika se sewe atlete twee medaljes verower, in 1912 het dic sewe atcte twee, in 1920 liet dic 13 atlete drie en in 1924 het die 12 atlete twee medaljes gewen. In 1928, 1932 e11 in 1960 is slegs een elk beliac1. Die atleetgetalle was tien, vier en agt onderslkeidelik." Hierdie artikel liet slegs op die gonc medaljes wat in 1908, 1912, 1920, 1928 en 1952 gewen is, gekonsentreer.

In 1947 het Prof Enist Jolkl gewaarslni dat SinidAdirika "bloedninin kans op die Olinipiade" sou hê.." Ln sv artikel liet liy daarop gewys dat Suid-Afrika se atletielsprestasies gestagneer het terwyl die res van die wêreld merkwardig verbeter liet. Hy het dit be. klemtoon dat Suid-Afirika voor die Eerste Wêreldoorlog '1 wêreldkrag in atletiek was, maar dat clic posisic drasties versleg het. Hy het verskillende atletieldlande se bevolkingsgetalle met livl prestasies vergelylk en tot die slotson gekom dat die Skandinawicse lande op daardie tydstip die lkern van wêreldatletick gevorm het. Ity let in daardie verband die volgende opnerlsing gemaak:

As hulle (Skandinawiese) opperheerskappy ooit bedreig gaan word, is dacu slegs een antropologiese groep wat in die nabye toekoms ' $n$ ernstige mededinger mag word, nl. daardie lede van die swartvellige Afrikatanse (sic) rasse wat kontak med hulle bewerkstellig en hal kennis van meer ervare atletiese lande aanwend. Wat gaan Suid-Afrika met sy nalurelle-atlete doen?:

Sedert die Olimpiese Spele van Mexiko-stad in 1968 liet talle Afrikalande meteoriese opgang in die atletiekwêreld gemaals." In antwoord op Joll se vraag omtrent Suid-Afilka se "naturelle-atlete", noct die blaan op die S.A. Amatenratletielsvereniging geplaas word. Nog lank voordat dic Nasionale Party aau bevind 
gekom het, het die behecrliggaan in 1931 beslitit on die klenuskeiding toe te pas. ${ }^{-7}$ Hicrdic beshit sou vir die daaropvolgende ses delkades 'n vemietigende effek op Suid-Afrika se atletickprestasics hê. Atletc soos Sydney Maree, Mark Plaatjies en Freddie Fredcricks (om net 'n paar van die mees onlangse gevalle te nocm) het hul heil in dic buiteland gaan soek. Daar kan slegs gespekuleer word hocvecl Reggic Walkers, Kenuctl McArthurs, Bcvil Rudds, Sid Atkinsons and Estlicr Brands in dic apartleiclsera nooit hul talente ten rolle ontwilklsel het nic.

\section{VERWYSINGS}

1. Van der Merice FJG. Aspiration towards Olympism. Report of the First Congress of the Olymuic Academy of Southern Africa, Port Elizabeth, 20.28 June 1990. (Pretoria). Olympic Academy of Southern Africa. 1990: 63-70.

2. Tan der Merive FJG. Suid-Afrika se rleelname an rlie Olimpiese Spele, 1908-1960. Ongepubliseerde Doktorale proefskrif. Potchefstroom: PU vir CHO, 1978; 44-45.

3. Official Report of the Olympic Games of 1908. London: The British Olympic Association, (1909): 51.

4. Laulscher L. The myth about Reg Walker and the 1.908 Olympic team. SA Sport Communico 1987; 8(2): 8.9.

5. Keartland HB. Persoonlike onderhoud. Johannesburg. 23 April 1976.

6. Keartland HB. Persoonlike korrespondensie, 31 Maart 1975.

7. Keartland HB. Persoonlike onderhoud. Johannesburg, 23 April 1976.

8. Kamper E. Encyclopedia of the Olympic Games. Dortunund: Harenlerg, 1972: 8.

9. Van der Merwe FJG. Suid-Afrika se deelname aan dic Olimpiese Spele, 1908-1960. Ongepubliseerde Doktorale proefskrif. Potchefstroom: PU vir CHO. 1978: 143. 145-146. 155.

10. Kamper E. Lexikon der 12000 Olynipioniken - Who's who at the Olympics. Graz: Leykam-Verlag. 1975:10.

11. Zur Megerle E. Die Geschichte der Olympischen Leichtathletik, Band 1. München: Bartels \& Wernit\%. 1968: 165.

12. Kamper E. Encyclopedia of the Olympic Games. Dortmund: Harenberg. 1972: 9.

13. Van der Merwe FJG. Suid-Afrika se deelname aan die Olimpiese Spele. 1908-1960. Ongepubliseerde Doktorale proefskrif. Potchefstroom: PU vir CHO, 1978: 250-253.

14. Official report of the ninth Olympiad, Amsterdam 1928 Amsterdam: Netherlands Olympic Committee, 1928: 436.

15. Viljoen JH. Persoonlike onderhoud, Pretoria, 10 September 1975.

16. Zur Megede E. Die Geschichte der Olympischen Leichtathletik. Band 1. Müchen: Bartels \& Wernitz. 1968: 198. 199 .

17. Van der Merive FJG. Suid-Afrika se deelname aan die Olimpiese Spele. 1908.1960. Ongepubliseerde Dokitorale proefskrif. Potchefstroom: PU vir CHO, 1978: 435.

18. Kamper E. Encyclopedia of the Olympic Games. Dortmund Harenberg. 1972: 35.

19. Quercetani RL. Athletics - a history of modern track and field athletics, 1860-1990, men and women. London: $L A A F$, 1990: 255; Joubert A. Persoonlike korrespondensie, 1984

20. Van der Merwe FJG. Suid-Afrikia se deelname uan die Olimpiese Spele, 1908-1960. Ongepubliseerde Dohtorale proefstirif. Potchefstroom: PU vir CHO. 1978: 629.

21. Jokl E. Ons allete het bloedmin kans op die Olimpiade. Fleur. 1947:2(4): 41-43.

22. Johl E. Ons atlete het bloedmin kans op die Olimpiarle. Fleur $1947: 2(4): 42$

23. Vun der Merwe FJG. Sportgeshiedenis: 'n Handleiding vir Suid-Afrikaanse studente. Stellenbosch: FJG Publikasies, 1994: 182-186.

24. Anderson $P G$. An investigation into the effect of race and politics on the development of South African sport (1970 1979). Ongepubliseerde Doktorale proefskif Siellenbosch: Universiteit unn Stellenbosch, 1979: 30

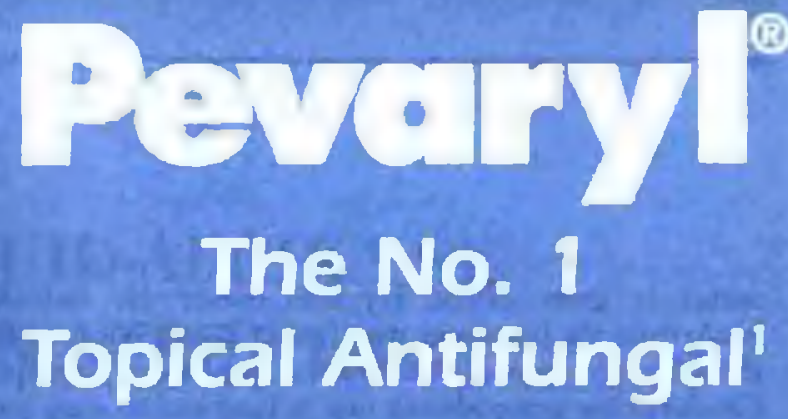

\section{The Topical Antifungal most prescribed by Dermatologists ${ }^{7}$}

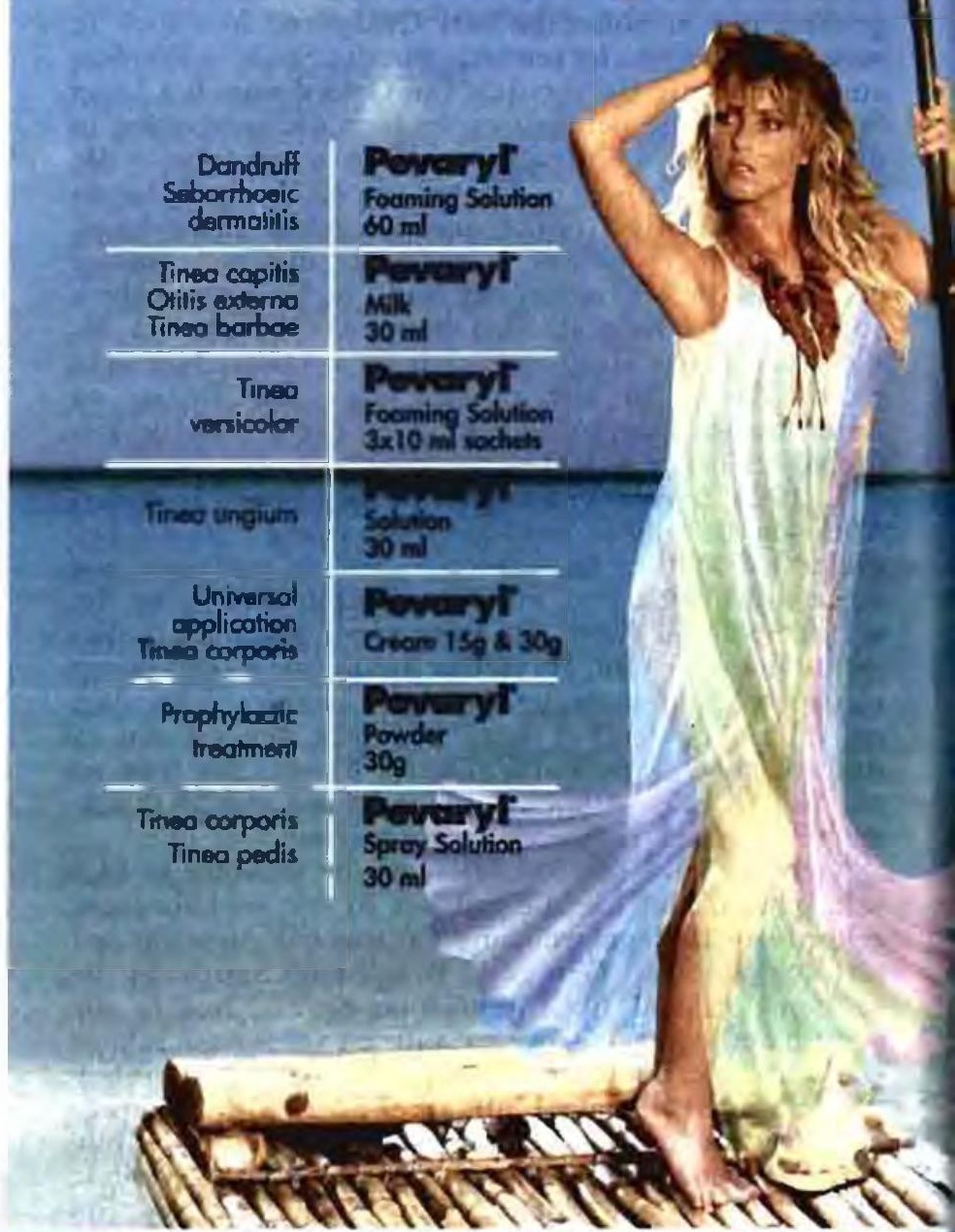

\author{
If you wish to see more, \\ call your Roche Syntex Division \\ Representative at (011) 974-5335
}
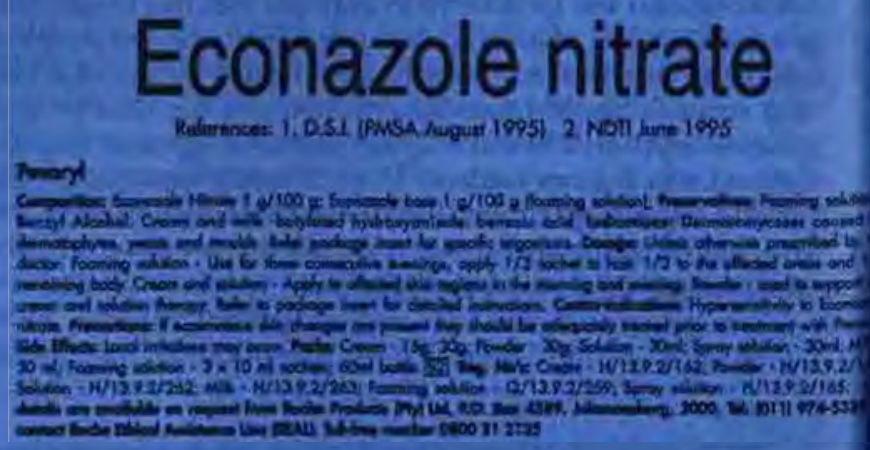


\title{
THE LIMITS TO HUMAN PERFORMANCE: A PHYSIOLOGICAL PERSPECTIVE
}

\author{
JA Hawley \& EJ Schabort
}

"Running records are still far below human physiological limits. The restraints on performance are psychological: good runners do not work as hard once they have set a record or won a medal."

Ryrler cl al (1976)

\section{HISTORICAL BACKGROUND}

Alliougl the purest csscuce of the sport of ruming is the competition and struggle of onc athlete against another, there has always been something matgical about the sctting of a worlel record, and its constant challenge burns lidse an cternal fanc for those individ. uals capalsle of such goals. Those athletes who liave broken a world record belong to al "super elite" group, for the stretcling of human capability, the brcaliug of bartiers, and the conquest of manown territory are pos. itive qualitics which definc mandsind as a whole. In atlı. letics, world records also help to give reason and incen. tive to those ontsturding efforts of a few atlletes and cusure that the great lianes of the pasi, as well as those of the present and the finture are never forget. teil. ${ }^{\text {si }}$

But just how fast cau men and women rum? What are the plyysiological limits to human performance? Will wonlen ever run as fast as menl over any distance? These and other questions lave recently becn the focus of consiclerible scicntific debate. $2 x=+1+7$

In the past, most theorics on these issues were large ly irrelexiunt because they were seldon based upon any scientilic rationale and logic but, ratlice, instinctive pre. dictions centred upon personal belicfs of the time. ${ }^{3.3 .}$ Lately, however, results from competilive ruming events have provided valuable insight for sports scicntists into several key integrative arcas of excreise plysiology: world records offer a franicwork for the disctission of how various plysiological factors interact as deterninants of performance. "1n:2,27.31:k,45 Considerable clfort is now locuscel on the study of atlletic perfor. mance, zasaw Indecel, diuing the past decades many attempts hare becn made at providing a matliemalical description of human performances based on the characteristics of the metabolic processes that provide clicinical energy to power muscle contrac.

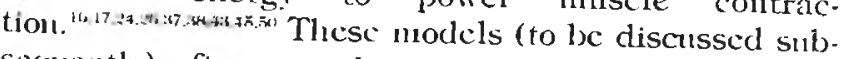
sequently) often provicle very accurate predictions of estinated and actual athletic performance. "2m.s. Understandibly, however, botlı coaches and atliletes are lighlly suspicious of sports scicutists who clain from thicir thicorctical matliculical morlels that "a

\section{Correspondence:}

Dr. Jolun A Hawley, F.A.C.S.M.

MRC/UCT Biocnergetics of Excreise Rescarch Unit Sports Science Institute of Soutli Africa

PO Box 115, Newliunds 7725

Phonc:(021) 686-7330 Fax:(021) 686.7530 mininum or no training is requircel for approsinaticty 16 days before a competition to arod a negittive cllect of trining (fatiguc) on competition performince!"

The purpose of this article is to investigitle the (wo Intion of luman performance and, within a plusiological franlework, cximule the 'Iinits' to filute athletic records. Obviously, a comprelensive discussion of all ruming evenls over a wide range of distances is berond the scope of this article. For this pirpose, the nucs's aunl women's record for the onc mile $(1,609.36$ min) has been chosen to focus on these and otlici questions.

\section{TIE PROGRESS OF HUMAN PERFORMANC:,}

At the tum of the contury a famous coach of the time stated of the men's world mile mark: ". . the men whes

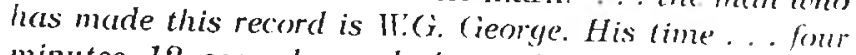
minutes 12 seconds. and the probability is that this record will never be broken". Almost onc hundral vaits later, Uhe record for the nicu's onc milc is some:30) sec (or approximately 215 w) faster (Table 1). Howcrex, 1 lic current women's record holder, P'anla Iran of Rrumiunia. weruld still be soundly beaten by Walter (icerge, It should be noted for posterity that William (ammings, the sole competitor ruming against George, eollapsicel 70 yards from the finish of the race fiom 'exhatustion'.

Table 1: The ecolution of the men s ond mile r lofore metre) world record since the first subfoul minute mile in 1.954

\begin{tabular}{|c|c|c|c|}
\hline Atlikete & Nationadity & $\begin{array}{c}\text { Perfonzuasice } \\
\text { (ninin:s(c) }\end{array}$ & $\begin{array}{l}\text { Date of } \\
\text { lecourel }\end{array}$ \\
\hline 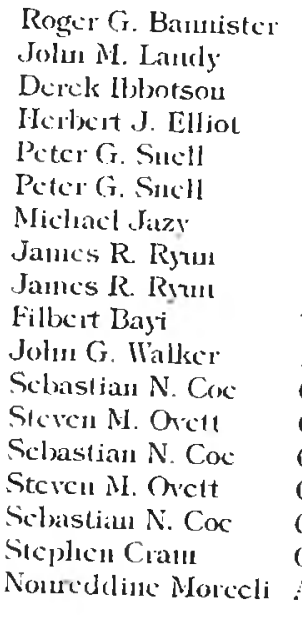 & 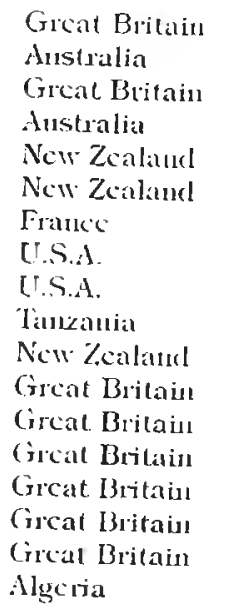 & $\begin{array}{l}3: 59.4 \\
3: 58.0 \\
33: 57.2 \\
3: 54.5 \\
3: \overline{4} 4.4 \\
3: \overline{4} 4.1 \\
3: 573.6 \\
3: 51.3 \\
3: 51.1 \\
3: 51.0 \\
3: 49.4 \\
3: 49.0 \\
3: 45.8 \\
3: 48.53 \\
3: 48.40 \\
3: 47.33: 3 \\
3: 46.32 \\
3: 44.39\end{array}$ & 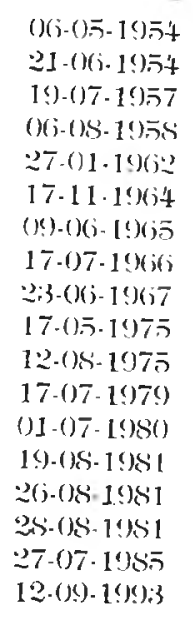 \\
\hline
\end{tabular}

Why then is the men's world marle for onc nile sitl so far allead of the wonen's? Car lla differences in inprovencints secn in the nucn's and womedi's recorel over the past forty years be cxplained on al plysiological
basis? 
Firstly, when considering the progress of hunan performance, it should be noted that men have participated in organised competitions over a wide range of starclard distances for more than 100 years. It is ondy dining the past 20.30 years that similar opportutitics have been afforded to women. Indeed, the Lnternational Anatcrur Athletic I'clcration (LAAF) did not sanction races for women that were longer than 1,000 in iutil 1967 when the $1,500 \mathrm{~m}$ and the nule werc "officially" recognised. Thic 10,000 $\mathrm{m}$ for women was not added until as recently as 1981 . It is somewhat unclear when the LAAF began to acknowledge the women's marathon ('t2.195 kn1), lut this crent was not contested in Olympic conpetition antil the Ios Angeles Gannes in 1984.

Secondly, an analy'sis of recent race times for women show that their workl records and best performances are not as consistent as those for men, particularly over the longer distances. "W of course, onc nught reasonably argine that this is as at restut of the shorter history of womcri's midelle ard long distance ruming aud the corresponding lack of competitirc opportunitics.

Thirclly, it is only diuing the past two decades that screral countries, most notably China and sone of the African nations, have acknowledged and belatedly enconraged woncen's participation in ligh level sport. Thus, when "pre-LAAF" times are consirlered, the time span available to critically and objectively analyse wonnen's performances should probably be lunited to the last quarter-ccntuy becausc of insufficicnt opportu. uitics for women to compete at alnost every level maks have. Given this position of historical disadvantage, it is perhaps not siuprising to find that since 1954 the rate of improrement of the women's world nile record is more than donble that of the men's mark ( $14.7 \% \mathrm{rrr}$. sus $6.3 \%$, respectivcly).

Finally, a closer exanumation of Tables 1 and 2 reveal that of the 18 men's mile world records since 1954 (acliered by 13 rumers), and the 17 women's best per-

Tablc 2: The evolution of the women's one mile (1,609 metre) world record since the first sub-five minute mile in 1954

\begin{tabular}{|c|c|c|c|}
\hline AtIileic & Nationality & $\begin{array}{l}\text { Performiance } \\
\text { (1ni11:sce) }\end{array}$ & $\begin{array}{l}\text { Date of } \\
\text { record }\end{array}$ \\
\hline Dianc Lcatlicr & Great Britain & $4: 59.6$ & $29.05-1954$ \\
\hline Dianc Lcather & Grcat Britain & $4: \overline{0} 0.8$ & 24.05 .19503 \\
\hline Diauc Lcatlici & Grcat Britain & $4: 45.0$ & $21 \cdot 09-1955$ \\
\hline 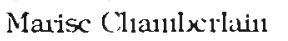 & New Zcaland & $4: 41.4$ & 08.12 .1962 \\
\hline Anuc Sinitl & Great Britain & $4: 39.2$ & $13.05-1967$ \\
\hline Aunc Snutli & rreat Britain & $4: 37.0$ & $03.06-1967$ \\
\hline Maria Gormunces & Holland & $4: 36.8$ & $14.06-1969$ \\
\hline Ellen Tittel & East Germiny & $4: 35.3$ & $20 \cdot 08-1971$ \\
\hline Paolal Cacclii-Pigui & Italy & $4: 29.5$ & $08 \cdot 08 \cdot 197: 3$ \\
\hline Natalia Marasesciı & Rollania & $4: 23.8$ & 21.05 .1977 \\
\hline Natalia Marasescu & Romania & $4: 22.1$ & $27 \cdot 01 \cdot 1979$ \\
\hline Mary Decker & U.S.A. & $4: 21.7$ & $26 \cdot 01-1980$ \\
\hline Lyudanila Vesclkova & U.S.S.R & $4: 20.89$ & 12-09-1981 \\
\hline Mary Decker-Tabb & IIS.A. & $4: 18.08$ & $09 \cdot 07 \cdot 1982$ \\
\hline Maricica Puica & Ronlania & $4: 17.44$ & $16-09-198^{\circ}$ \\
\hline Mary Slancy-Decker & U.S.A. & $4: 16.71$ & $21.08-1985$ \\
\hline Pandla Ivan & Roniauia & $4: 15.61$ & $10-(07.1989$ \\
\hline
\end{tabular}

formlances (set by just 11 rumers), only iwo recometh have becn attancel by dfriean runners. (onsiclering the ceurent athletic clominance of the African nat ionts, most notably Kenya, Lathiopia, and Morecen over a wirke mange of distances $(3,000 \mathrm{ml}$ to the marathon) and cremts (road races, track, and (cross comitry), this is somewhint supprising. With this rastly different backgromet, and with reference to the evolution of the worlel recosel for the mile for the past forty years (Tables 1 and 2 ), onc issue warrants fintlier discussion.

Although it was not until May 6, 1954, that Roger Banuister becanc the first man in run muler font min. utes for the mile (3:59.4), it was problably onc rear cirl-

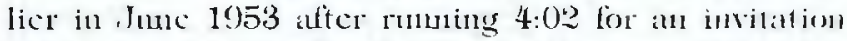
mile race at a schoolboys athleric mecting, that Biuntister and his coach, Franz Stampll, realiscel hic was capable of running a 'silb four'. In contrast, Jolun Laudy fiom Australia, who loy April 1954 had already run the nile in tuncter 4:0:3 on no fewer thiu sis differ. cut occasions, stated "...the four minute barrier is a brick wall. I shall not attempt it again." Yet, only 1 wo wceks ufter Baunister had secured funce for life as a resull of his famous run at Oxford, Landy ran $3: 58$ for the mike aud becanc the new world record holder. As Bannister later summarised "... though physiology may indicate" respiratory and cardiovascular limits to muscular effort. psychological and other factors beyond the ken of phlysioloyy set the razor's edge of defeat or victory and deterymine how closely the athlete approaches the ahsolute limits of performance"."

In this rein, and with reference to the wonen's record, it was perhaps much more than prue coincidence rhat Diate Leallier of Creat Britain became the first female to break five minntes for the mile just three wecks allice Bannister sed his historic mark. This and otler similar feats hare led certain rescarchers to conchude thar "... the barrier to be overcome by the rumner who wants whe a champion is psychological. The last record sit and the willingness of athletes to try to break it are the determining factors for the next record. "The inliercuce is that a higlly competitive situation brings oul in llic fincst of atluetes a kevel of performance of which cern they are incapalble nuder less challenging circumstances. The nagnitude of this effect, which is almost inpossible to quiutify, appears to have bech ignored by many researchers who have emploved "mathematical cquations" to predict fitture performance.

\section{CAN IMPROVEMINTS IN PHYSIOLOGY EXPLAIN THE IMPROVEMENT IN PERFORMLNCE?}

There are a number of key phesiological factors related to successfiu midale-d istiulec and (listance rumning performance. These include: (i) a high $(>70 \mathrm{ml} / \mathrm{kg} / \mathrm{min})$ maximal aerobic power (VO:max); (ii) the ability to utilise a high percentage of VOsman for sustained periods; (iii) the ability to sistain high ( $>20 \mathrm{~km} / \mathrm{hr}$ ) runuing specols and resist muscular fatignc; (iv) a fatst rouuing specol at the "lactate thereshold"; (v) an efficient/comomical ruuning technique, and (vi) a high anacrobic (oxygen)independent) capacity. These determinauts of sujerior performance have been extensively reviewed else. where." ments in any one (or more) of these factors call cxplain the large improvements in human perfornlauce orer the past century. 


\section{On-the-spot pain relief.}


With regard to a riumer's maximal aerobic power, Sid Robinson and colleagues working at the Harvard fatigue laboratory, reported very high VO elite rumers over fifty years ago. ${ }^{+1} \mathrm{~A}$ VOmax value of 82 $\mathrm{ml} / \mathrm{kg} / \mathrm{min}$ was measured for Donald Lash, one of the first ruuners to rum two miles in less than nine minutes. These investigators also reported several other rumers

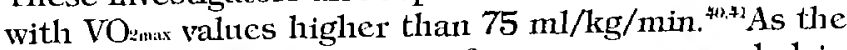
highest VOmas ever reported for a rumer recorded in the modern era in a reputable laboratory is 85 $\mathrm{ml} / \mathrm{kg} / \mathrm{min}$ for Dave Bedford, ex-world record holder for $10,000 \mathrm{~m},{ }^{5}$ it seems unlikely that increases in maximal acrobic power are responsible for the large improvements in the world records for varying athletic events.

Instead, it may be that the gradual improvements in performance by elite runners are more related to their improved ability to sustain a higher fraction of VO"max in competition, and also to better ruming economy and techuique." This view is consistent with the evolution of training practices this past century. For cxample, from the carly 1900's to the late 1960's, there was a steady increase in the frequency, intensity and duration of training so that by the early 1970's most track ruuners were undertaking several hours of training a day on a week to week basis. Since that time, the training regimens of top numers has not changed dramatical$1 y .33,40.47$

Finally, an analysis of world recorrls at distances from one mile to the marathon reveal that it is mainly an increase in specific endurance (i.e. the ability to resist fatigue) rather than any enhancenent in basic speed or "anaerobic" power that is responsible for the gradual improvements in many events over the past fifty years." The dominant effect of this improvement in specific endurance or fatigue resistance (i.e. the ability to maintain a given speed) is hidden by the tradition to time races at a constant distance, rather than to measure the distance a runner could cover in a specific time. To illustrate this point, in 1969 Derek Clayton of Australia ran a marathon in 2 hr 08:32, at an average velocity of $\sim 328 \mathrm{~m} / \mathrm{min}$. This was slightly faster than the mean ruwuing speed for the men's one mile record some hundred years previously set by Britain's Cadet Marshall in 1852 at $\sim 326 \mathrm{~m} / \mathrm{min} .{ }^{73 . \overline{1}}$ In other words, Clayton demonstrated a specific endurance more than 26.2 times greater than Marshall. In pliysiological terms, at the same speed, Clayton was able to run 26 times firther than Marshall! Perhaps more importantly, Clayton possessed a relatively modest VOmmx of only $69.7 \mathrm{ml} / \mathrm{kg} / \mathrm{min},{ }^{11}$ illustrating that it is a runner's maximal speed and economy of motion at race pace, rather than her/his VO: was which predicts atlletic performance. $14: 36$

Apart from the physiological improvements associated with superior performance, there are, of course, other factors which may explain why world records have continued to fall. The introduction of synthetic running tracks can improve competitive performance by $2-3 \%$ compared to older traditional surfaces like grass and cinders. ${ }^{(9,4)}$ Professionalism, conmercialism, and more numerous competitive opportunities today compared with forty years ago mean that more potential record setters have the chance to train and compete on an almost full-time basis. It is also possible that the use of banied substances may have contributed to the improved performances of some atliletes. . $^{13.15,31.49}$
However, whether the modern athlete's nutritional practices have contributed to their improved training capacity and race performances is somewhat donbtful:

\section{MATHEMATICAL MODELLING OF HUMAN RUNNING PERFORMANCE}

As noted previously, there have been many attempts by sports scientists to "model" or describe atluetic performance based on a complex interaction of many input: variables such as the upper linits of scveral metabolic processes involved in power production, and the inptu dose-effect of training interventions. Many more factors, however, remain to be specified and preciscly quantified: ${ }^{: 3}$ Nevertheless, several investigators have presented models that describe, with a high degree of accuracy, ruwuing performances over various distances. For example, Ward-Smith ${ }^{4-5}$ proposed a model for mate performances where the average absolute error between estimated and actual ruming times for all clistances fiom $100 \mathrm{~m}$ to $10,000 \mathrm{~m}$ was only $0.86 \%$. Although at first sight this model appears very acci1rate, it was eriticised by other workers in the field ${ }^{\text {is }}$ bccatse it failed to take into account the well doct1mented progressive decline in the aerobic power ontput that can be stustained as the distance run increases. For example, even a world-class rumer is only capable of

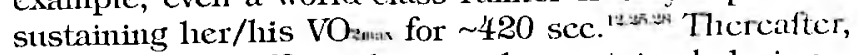
the fraction of $\mathrm{VO}$ :max that can be sustained diuing a race decreases linearly from $100 \%$ at time t, to $85-90 \%$ for a $60 \mathrm{~min}$ race, $80-85 \%$ for a 120 min race, $75-80 \%$ for a $180 \mathrm{~min}$ race and so on. ${ }^{3728}$ Talking this factor into account, Peromet and Thibatut ${ }^{\text {isi }}$ suggested a modification of Ward-Smith's ${ }^{4 n}$ hyperbolic model which reduced the absolute error between actual and estimated running times for: races from $60 \mathrm{~m}$ to the marathon for both men and women to only $0.73 \%$. The complete model of ruwning performances proposed by these and other: worker's not only provides a quantitative description of cndurance capability, but also an estimation of the relative contributions of the various oxygen dependent and oxygen independent power systems to the total work output according to the duration of the race. ${ }^{\text {la: }}$ 'The theoretical considerations of such models are complex and outside the brief of the current paper.

\section{THE LIMITS TO HUMAN PERFORMANCE: WHERE TO FROM HERE?}

Perhaps of greater interest and relevance to athletes and sports scientists alike are the projected improvements in running times for various distances based on the various mathematical models. Table 3 lists the projection of both the men's and women's world record for

Table 3: Projection of the men's and women's world mile records

\begin{tabular}{lcccc}
\hline & \multicolumn{4}{c}{ Year } \\
\cline { 2 - 5 } & 2000 & 2028 & 2040 & $\begin{array}{c}\text { Ultimate } \\
\text { Perfornunce }\end{array}$ \\
\hline \multirow{2}{*}{ Men1 } & $3: 41.96$ & $3: 33.29$ & $3: 29.84$ & $3: 18.87$ \\
Wonncn & $4: 10.79$ & $4: 00.83$ & $3: 59.82$ & $3: 43.24$ \\
\hline
\end{tabular}

Data arc from Pcronnct and Thibault, 1989 
the mile, along with the 'ultimate performance' for that distance. ${ }^{\text {in }}$ As can be seen, a 3:30 mile is projected for men by the year 2040 , even though in 1954 Roger Bannister forecast that this mark would have been accomplished by 1990." In order to attain stich a level of performance, the miler of the future will need a VO:max of $\sim 91 \mathrm{ml} / \mathrm{kg} / \mathrm{min}$ while also possessing stuficient basic speed to run the quarter mile in arotund 44 sec and the $800 \mathrm{~m}$ in around 1:42. Although such a range of performances by the same rumner seem some. what unrealistic at first sight, the current world records for the $400 \mathrm{~m}$ and $800 \mathrm{~m}$ already stupass these 'hypothetical' marlss ( $43.29 \mathrm{sec}$ for $400 \mathrm{~m}$ by Harry 'Butch' Reynolds; 1:41.73 for $800 \mathrm{~m}$ by Sebastian Coe). Indeed, as discussed previously, it is likely that future improvements in world records will come not from any increase in instantancots speed or power derived from the oxygen-independent "anaerobic" patliways, but rather au increase in fatigue resistance or specific endurance. This being the case, then one might reasonably argne that the current men's world mile mark (Table 4) is already well overdue for revision. There are presently many rumners with sufficient basic speed over botll 400 $\mathrm{m}$ and $800 \mathrm{~mm}$ who, with the development of sufficient specific endurance, sliould be capable of significantly reducing the present record. Indeed, according to clata derived from performance tables comparing the various rumning distances from $800 \mathrm{~m}$ to the maratlon, ${ }^{1: 3}$ the men's world mile record ought to be arotund $3: 42$ in order to be comparable with the present 5,000 $\mathrm{m}$ (1.2:44.39 and 10,000 $\mathrm{m}$ (26:43.53) world best times, both held by Ethiopia's Haile Gebresilassie.

Table 4: The fastest mile: $A$ brealcdown of Noureddine Morceli's world record

\begin{tabular}{lcccc}
\hline & \multicolumn{4}{c}{$\begin{array}{c}\text { Distance } \\
\text { (In) }\end{array}$} \\
\cline { 2 - 5 } & 400 & 800 & 1,200 & 1,600 \\
\hline $\begin{array}{l}\text { Lap times } \\
\text { (sec) }\end{array}$ & $\mathbf{5 4 . 9}$ & $\mathbf{5 7 . 7}$ & $\mathbf{5 7 . 3}$ & $\mathbf{5 4 . 5}$ \\
$\begin{array}{l}\text { Total time } \\
\text { (min:sec) }\end{array}$ & 0.54 .9 & $1: 52.6$ & $2: 49.9$ & $3: 44.39$ \\
\hline
\end{tabular}

Set at Reiti, Italy, 01112 Scptember $1993 @ 1838$ 11r. Ambicut. tcmpcrature 20 C, relativc humidity 50\%. Data arc from Zur Megedc and Hymans, 1995.

Finally, it has recently been proposed that for certain runuing distances, the performance of women lliay equal those of men within the next few decades. ${ }^{\text {th }}$ Althougl this seems extremely uulikely, the results from a recent study from this laboratory" do suggest that for ultra-marathon events at least, women may be closing the gap. Bam et al.," found that when male and female rumers were matehed for age, training history and race time over $56 \mathrm{~km}$, the women outperformed the males over the ultra-marathon distance of $90 \mathrm{~km}$. In fact, the "crossover" point at which the women become faster than their male counterparts was after $\sim 66 \mathrm{~km}$. This was in spite of the males being much faster over all distances from $5 \mathrm{~km}$ to $42 \mathrm{~km}$. It was hypothesised that women ultra-marathon rumers may have gieater fatigue resistance than do equally-trained men.: Althougl the precise mechanisms for this greater specific endurance is not clear," it may simply be related to the smaller sizes and lighter body mass of the females.

Figure 1: The progression of the men's (filled circles) and women's (open circles) world record for one mile (1,609) $m$ ) since 1954. The extrapolation of the lines of best fit. for the data sets would estimate that by the Sydney Olympic Games, to be held in the year 2000 , the men's record will be 3:42 and the women's around 4:00.

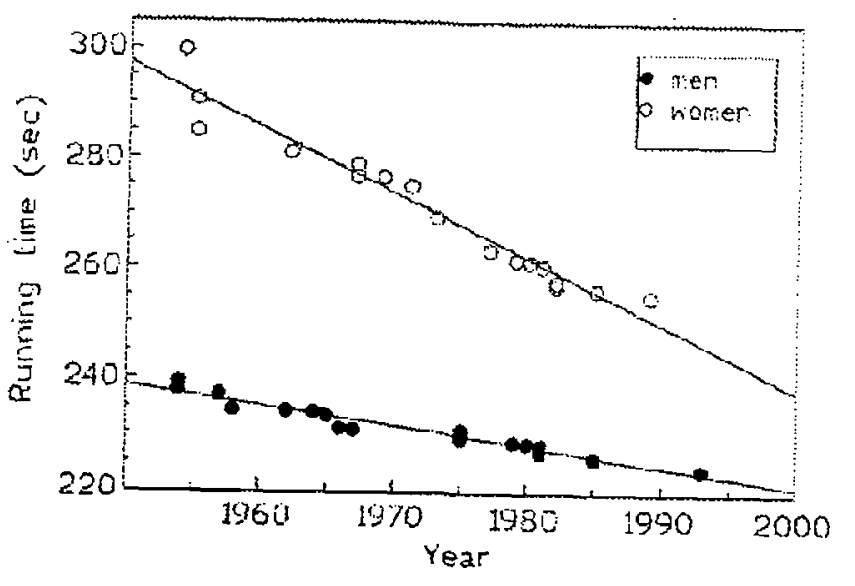

\section{CONCLUSION}

In conclusion, it seems likely that any future improvements in the current world records for distances fiom one mile to the marathon will be achiered by those ath. letes able to stustain high rumning speeds and resist the onset of muscular fatigue, rather than any significant. increase in absolute rumming velocity per se. For this to lrappen, the runners must be in a highly competitive situation which will bring out the highest level of performance: the magnitude of this psychological effect seems to have been somewhat overlooked by those sports scientists who have employed mathenatical models to describe and predict future race performances. While it seems anlikely that women will ever beat men over any distance until such time that. they can rou shorter track distances as fast as the males, one might speculate that women's performances may one day equal those of the leading men in very long (i.c.) $42 \mathrm{~km})$ distance races.

\section{REFERENCES}

1. Andrews H. Training For Athletics and General Health. Arthur Pearson Pub. London. 1903.

2. Bam J, Noakes TD, Juritz J. Dennis SC. Could women outrun men in ultra-marahon races? Medicine and Science in Sports and Exercise (in review).

3. Bannister RG. The First Fou Minutes. Putman, London. 1955. 
4. Bannister RG. Muscular effort. British Medical Bulletin, 1956; 12: 222-225.

5. Bergh U. Physiology of Cross-Country Ski Racing. Human Kinetics, Champaign, Illinois, 1982.

6. Brandon IJ. Physiological factors associated with middle distance running performance. Sports Medicine, 1995; 19: 268-277.

7. Brandon $I J$, Boileau RA. The contribution of selected variables to middle and long distance run performance. Journal of Sports Medicine and Physical Fitness, 1987; 27: 157-164.

8. Brandon LJ, Boileau RA. Influence of metabolic, mechanical and physique variables on middle distance ninning. Journal of Sports Medicine and Physical Fitness, 1992; 32: 1-9.

9. Coetzer P, Noakes TD, Sanders B, Lainbert MI, Bosch AN, Wiggins T, Dennis SC. Superior fatigue resistance of elite black South Afican distance runners. Journal of Applied Physiology, 1993;75:1822-1827.

10. Costill DL Inside Rutnning: Basics of Sports Physiology. Carmel, In: Benchinark Press, 1986: pp. 1-189.

11. Costill DL, Branam G, Eddy D, Sparks $K$. Determinants of marathon running success. Internationale Zeitschrift fur Angewandte Physiologies. 1971; 29: 249-254.

12. Costill DL. Fox EL. Energetics of marathon running. Medicine and Science in Sports, 1969; 1: 81-88.

13. Daniels J, Gilbert JR Oxygen power... : Performance Tables for Distance Runners. Tempe. Arizona, 1979.

14. Ekblom B, Berglund B. Effect of erythropoietin administration on maximal aerobic potver. Scandinavian Journal of Medicine and Science in Sports, 1991;1:88-93.

15. Ekblom B, Goldberg AN, Gullbring B. Response of exercise after blood loss and reinfusion. Journal of Applied Physiology. 1972: 33: 175-180.

16. Ettema JH. Limits of human performance and energyproduction. Internationale Zeitschrift fur Angewandte Physiologie, 1966; 22: 45-54.

17. Handelman $G H$, Smith DC. Comparison of running and swimming records. Sportwissenschaft, 1980; 2. 161-168.

18. Hawley JA. State of the art training guidelines for endurance performance. South African Journal of Sports Medicine, 1995; 2: 7-12.

19. Hawley JA, Hopkins WG. Aerobic glycolytic and aerobic lipolytic power systems. A new paradigm with implications for endurance and ultra-endurance events. Sports Medicine, 1995: 19: 240-250.

20. Hawley JA, Dennis SC, Lindsay FH, Noakes TD. Nutritional practices of athletes: Are they sulb-optimal? Journal of Sports Sciences, 1995: 13: S75-S78.

21. Havley JA, Myburgh $K H$, Noakes TD, Dennis SC. Training techniques to improve fatigue resistance and enhance endurance performance. Journal of Sports Science (Supplement), In press, 1996.

22. Joyner MJ. Modelling: Optimal marathon performance on the basis of physiological factors. Journal of Applied Physiology, 1991; 70: 683-687.

23. Joyner MJ. Physiological Limiting Factors and Distance Running: Influence of Gender and Age on Record Performances. In: Holloszy JO(Editor), Exercise and Sports Science Revieus, 1993; 21: 103-133.

24. Keller B. A theory of competitive running. Physician Today. 1973; 26: 43-47.

25. Leger D, Mercier D, Gauvin L. The relationship between : $\%$ VOmux and running performance time. In: Landers DM (Editor). Sport and Elite Performers, Volume 3. Human Kineties Publishers, Champaign, Illinois, 1986; pp.113120.

26. Lloyd BB. The energetics of running: an analysis of world records. Advances in Science, 1966; 22: 515-530.

27. Lloyd $B B$. World running records as maximal performances. Oxygen debt and other limiting factors. Circulation Research, 1976; XX, XXI: 218-226.

28. Londeree BR. The use of laboratory test results with long distance runners. Sports Medicine, 1986: 3: 201-213.

29. McMahon TA, Greene PR. Fast runuing tracks. Scientific American, 1978; 239: 148-163.

30. McMahon TA, Greene PR. The influence of track compliance on running. Sournal of Biomechanics, 1979: 12: 893-904.

31. Mognoni $P$, Lafortuna $C$, Russo $G$, Minetti A. An analysis of world records in three types of loconotion. European Journal of Applied Physiology, 1982; 49: 287-299.

32. Morton RH. The supreme runner: What evidence now? Australian Jounal of Sports Science, 1985; 3: 7-10.

33. Morton RH, Fitz-Clarke JR, Banister EW. Modelling human performance in running. Journal of Applied Plyysiologly. 1990: 69: 1171-1177.

34. Noakes TD. Implications of exercise testing for prediction of athletic performance. Merlicine and Science in Sports and Excrcise, 1988; 20: 319.330.

35. Noakes TD. Lore of Running. Oxford University Press. Cape Town, 1992, pp. 266-270.

36. Noakes TD, Myburgh KH, Schall R. Peak treadmill running velocity during the VOinur test predicts runing performance. Journal of Sports Science. 1990: 8: 33-45.

37. Peronnet F, Thibault G. Analyse physiologique de la performance en course à pied: révision du modéle hyperbolique. Journal of Physiologie (Paris), 1987: 82: 52-60.

38. Peronnet F, Thibault $G$. Mathematical analysis of nuning performance and world running records. Journal of Applied Physiology, 1989; 67: 453-465.

39. Robertson RJ, Gilcher R, Metz KF. Hemoglobin concentration and aerobic work capacity in women following induced erthyrocythemia. Journal of Applied Physiology. 1984; 57: $568-575$.

40. Robinson S, Dill DB, Robinson RD, Trankoff SP. Waymer JA. Physiological ageing of champion rumers. Journal of Applied Physiology, 1976; 41: 46-51.

41. Robinson S. Edwards $H T$, Dill DB. New records in human power. Science, 1937: 85: 409-410.

42. Rumball WM, Coleman CE. Analysis of running and the prediction of ultimate performance. Natture, 1970: 228: 184185.

43. Ryder $H W$, Carr HJ, Herget $P$ Future performance in footracing. Scientific American, 1976: 234: 109-119.

44. Saltin B, Astrand P-O. Maximal orygen uptake in athletes. Journal of Applied Physiology. 1967; 23: 353-358.

45. Ward-Smith AJ. A mathematical theory of raming. based on the first law of thermodynamics and its application to the performance of world-class athletes. Joumal of Biomechanics, 1985; 18: 337-349.

46. Wells CL, Pate PR. Training for performance of prolonged exercise. In: Lainb DR, Murray R(Editors). Perspectives in Exercise Science and Sports Medicine Volume 1. Prolonged Exercise, Benchmark Press, Indianapolis, 1988: 357-391.

47. Wilt F. How They Train. Volume II. Long Distance (second Edition). Track and Field News, Los Altos. California. 1973 ; pp. 1-126.

48. Whipp BJ, Ward SA. Will women soon outrun men? Nature, 1992; 355: 25.

49. Williams MH, Wesseldine S, Somma T, Schuster R. The effect of induced erythrocythemia upon 5-mile tradmill itum time. Medicine and Science in Sports and Exercise. 1981: 13: 169-175.

50. Wilkie DR. Equations describing potver input by humans as a function of duration of exercise. In: Cerretelli $P$. Whipl BJ. (Editors), Exercise Bioenergetics and Gas Exchange. New York: Elsevier, North Holland, 1980: 75-80.

51. Zur Megede E, Hymans R. Progression of World Best Performances and Official IAAF World Records. International Amateur Athletic Federation. Multiprint. Monaco, 1995. 


\section{PSYCHOLOGICAL PREPARATION FOR OLYMPIC ATHLETES}

\section{INTRODUCTION}

After winning 7 gold medals at the Montreal Olympics Mark Spitz said: "At tliis level of pliysical skill, the difference between winning and losing is $99 \%$ psychological".' The reason is that elite athletes in a specific sporting discipline are, to a large extent, fairly equal on physiological, teclnical and tactical factors. When elite atliletes compete the one who wins is usually the one who is mentally the strongest on that given day. Whereas plysical abilities are seen as relatively stable, psyclological factors primarily determine the daily variations in performance". Rushall goes as far as advocating sport psychology as "the key to sporting excellence and success"

Current thinking and practice in applied sport psychology assumes that the athletes' level of performance is a direct consequence of the way athletes are thinking and feeling.' Sport scientists and athletes acknowledge that a negative psychological set, such as feelings of frustration, fear, anger and worry, negative thonghts and imagery, and task-irrelevant thoughts typically impairs performance. Sport competitions are stressfil events. Athletes who overteact to the challenge experience anx iety and tension which can adversely affect physiological and cognitive processes to snch an extent that they perform below their potential and expectations. The athlete displaying a palpitating leart, a dry nouth, tight or shaky nurscles, rapid breathing, a tight stomacl, poor concentration and winfocused negative thoughts cannot hope to perform optimally. . $^{-5 i}$

What is needed is a positive psychological set that mobilizes the physiological reactions esseitial for peak performance. The likelihood of achieving peak performance increases dramatically as athletes consistcntly generate the mental climate that has been identified by numerous studies ${ }^{1,7,8}$ to optimize ontput: Athletes do their best when relaxed and alert: The psychological ideal performance state is difficult to sustain during high-powered competition and years of tedions training." To becone an Olympic athlete it has to be experienced consistently and once at the Olynipic Ganes it has to be right there.

\section{CHARACTERISTICS OF SUCCESS}

Although no set distinguishable "athletic personality" has been identified in the sport psychological literature, a certain psychological profîle emerges again and again when sport scientists examine successfinl elite athletes, regardless of the source of the data or the nature of the sport.'

Siccessful elite athletes display the following characteristics and psychological slkills:

1) Consistent self-regulations of aronsal (fecling cnergized yet relaxed)

2) Superior concentration (being appropriately focused)

3) High self-confidence (positive attitude) aud

4) Determination, commitunent and control (clcar sense of direction, meaningfulness and aware. ness).

\begin{abstract}
Allowing for individual variations, the above-nentioned psyclological commonalities are necessary predispositions for the psychological ideal performance state to be propagated and maintained. The ideal perfornuance state does not just happen. The mental skills needed to achieve and maititain the ideal performance state are lcaned through knowledge and practice just as the plysical skills and strategies of the sport are leaned and practised. 'The best preparation or contelown to competition rituals involves behavional sequences that get the athlete physically and mentally ready for cont. petition. The pliysical preparations and training has to go liand in liand with the inclusion of psycloological principles and procedires if athletes are to miaximise their chances of being ready to peak at competition time. 3.10

"The ultimate goal of psychological skills training is for each athlete to learn how to create consistently at: competition time the ideal performance state (thonghts, feclings, bodily responses) typically associated with his or her peak performance." "Psyclological skills training progranmes cau help athletes plau effective behavionral protocols or preparation ritnals that can be used regularly as pre-conpetition and conpetition readying procedures.
\end{abstract}

\section{PSYCHOLOGICAL SKILLS TRAINING OUT. LINE}

Comprehe:1sive psychological skills training pro. grannmes typically follow a set structure with three distinct pliases."

1. Education phase: This pliase involves explaiuing to athletes the importance of developing and learining psycloological skills and low these skills affect peiformance.

2. Acquisition phase: This phase focuses on strutegies and teclmiques to lean the different psycloological skills. Rather than imposing a standard packatge on the atllete, it is important to develop specific psy. chological strategies tailored to the atlolete's nuiquic needs, ability and strenglis as well as the specific: demands of the sport

3. Practice phase: This phase lats three main objectives: to automate skills throngl overlearuing, to instruct athletes to consistcintly integrate psychological skills into their perfornance sitnations, and to simulate skills that the athlete will draw on diring the actual competition.

The most connter-productive tine to implenent a psychological skills training programme is after the stat of the competitive season and there is concern becallse athletes are performing below their potential. At this time psychological skills training amounts to a quick-lix solution and is rarely effective. It can also be detrinenttal to make atliketes aware of psycloological aspects of conpetition that should be addressed when there is insufficient tinte to learn the new psychological skills necded for control. ${ }^{\text {mis }}$

The nost productive time to implement a psycholog- 
ical skills training programme is during the off-season or pre-season (long before the competitions begin) when athletes are well-rested and are in a relatively pressurefree situation, and there is sufficient time to learn new skills. ${ }^{1: 3}$

Mere exposure and one-off practice of psychological skills training tecluniques by 110 meaus prepare atliletes for snccessful implementation of these skills in Olympic competition. Rather, they must beconc autonatic and second-nature to be effective. Gould, Eklund and Jacksonl $^{14}$ reported that 1988 U.S. Olympic wrestlers who had won medals had internalized their mental strategies to the extent that they reacted antomatically to adversity, whereas non-medalists did not have their coping strategies as internalised and had to make a conscious effort to use them when faced with mishaps. They even suggested that the specific coping strategy used may not be as important as the elite atlulete's ability to produce that strategy in an antomized mode. For psychological sliils and coping strategies to beconle antomatic and second nature, requires the long-tern practice of stich skills that need to be integrated witl physical skills training., ${ }^{\bar{n}, 411}$ It can take atllletes several months to a year to master the new psychological slitls and successfilly apply them in actual competition. Orlick ${ }^{1 i}$ reported that this process usually takes the highly commuited athletes about three years of regular: practice before things really come together mentally for them.

\section{Leading up to the Olympics}

With respect to providing the most effective service during the final months leading up to the Olympics, it is imperative not to make major clianges to the athletes' routines and it is not the time to introduce new psycliological, plysiological or teclinical concepts. By this time athletes and coaches should have their plans together. Typically, the closer one gets to the Olympies themselves, the aim should be to refine and finc-tune the skills that have already been practised. An appropriate approach focuses on suggestions low athletes nught handle particular concerns such as readiness, plaus for distractions, preparation througl simulation, familiarisation with the Olympic site, lack of personal space, dealing witl media, dealing witlı interpersonal/personal conflicts, developing a plan for being and fecling in control in the Olympic environment, ensuring that at 11 letes and coaches have an effective pre-event plan, cspecially just prior to the start of the event, how to control pre-cvent anxicty, guarding against overtraining, and emphasizing the need for adequate rest when faced witll high levels of stress. ${ }^{1 *, 15,16}$

\section{Psychological skills training guidelines}

Thie following psycliological skills and performance culuancement strategies are structured in accordance with the psychologieal characteristics displayed by successful elite athletes discussed earlicr ill this article. Numerous sport psychology consultants have documented the application of these teclniques in preparation for and during Olympic games. ${ }^{17.18 .12 \pm 0.21 \cdots 2}$ It sliould be noted that a psychological skills training programme cannot be expected to compensate for weaknesses or deficiencies in other parts of an athlete's programme (e.g. inadequate plysical capacity, training programme, coaching etc). ${ }^{13}$ A psychological sliblls training pro- gramme must be viewed as a critical part of the athletic programme and the psychological unput should be placed in the perspective of the athlete's life and the athlete's daily functioning. A psychological skills training progranme is a signilicaut but only onc of many parts of an athlete's sport experience."

\section{The self-regulation of arousal}

The inverted U-hypothesis has been a popular theory to cxplain the relationship between arousal or anxiety and athletic performance. Initially, performance improves with increased arousal, up to a certain point, after which further increases in arousal produce a deterioration in performance. The eritical point lias been referred to as the point of optinal activation.

The optimal level of arousal varies as a function of the complexity of the task and the skill level of the ath. lete. For example, for activitics that recuire precise fine 111otor skills involving steadiness of control of unwanted muscle activity (e.g. high-board diving), very little arousal can be tolerated witlout impairing performance. However, for tasks that require minimal fine motor precision (e.g. weight lifting), a ligher level of arousal can be tolerated before performance is inpaired."

When atluetes reach an optimal level of arousal they should feel higlily energised but still relaxed. This high cuergy state has frequently been described by elite athletes as a fceling of joy, ecstasy, intensity, boldness, inspiration, cliallenge, and being "charged" or "lot".

Despite the lueightened arousal level, atliletes should be physically relaxed with their muscles being loose and able to perform flitel movements. Athletes who find thenselves in this optinnm level of arousal will experience a sense of inner calm and a high degree of concentration concurrent with a time-space disorientation (nsually the sense of time being slowed down). The fear of failure is completely absent.

Sport scientists generally agree that most performance crrors arise not so much from tuncler-atousal, but rather from over-arousal, when athletes experience difficulties coping with competitive anxicty." Thus, athletes need to learn self-monitoring and recognize how their cunotiond states affect their performance during competition.

\section{Progressive relaxation}

Jacobson advanced the concept of progressive relaxation after obscrving that an auxious mind cannot exist within a relaxed body. ${ }^{27}$ Relaxation of a 111 scle group was found to be physiologically incompatible witl contraction of that sanc gronp. Therefore, relaxation training was seen to conbat the anxiety response by climinating tension in the muscles.

Progressive relaxation involves systematically contracting and then relaxing one major muscle group in the body before progressing to the llext muscle group while focusing on the different sensations of tension and relaxation. With practice a person can detect tension in a specifie nutscle or area of the body, like the neck, and then relax that muscle.

The advantage of the method of progressive relaxation is that atliletes can tale fiul control of their level of arousal. An athlete who has mastered the teclunique after several months of regular practice should be able to elicit the relaxation response witlin seconds of encotutcring a stressful stimulus. 


\section{Autogenic training}

Autogenic training consists of a series of exercises designed to produce two pliysical sensations: warmith and heaviness. The feeling of warmth is ascribed to the dilation of the blood vessels with a resultant increase in blood flow, while the sensation of heaviness is clue to the relaxation of muscle groups.

It usually takes several months of daily practice to become proficient in the use of antogenic training. Onec mastered, it is especially usefil for fast relaxation in a competitive environment and can be effectively applied in the field of sport.

\section{Concentration}

Atlletes must focus attention on the relevant cues in the environment and maintain the appropriate attentional foci for the duration of the competition. Concentration problems are usually caused by an inappropriate attentional focus and occur when athletes become distracted by thoughts, emotions, or other events.

The athletes should be focused on the present and be conscious only of what they are doing at that specific moment. They should have no thouglits about the past or fiture because these are irrelevant cues that often inpair concentration and lead to reduced performance. Sonc athletes find it difficult to forget what has just happened, especially if it was a bad mistalce. Thinlking about the future usually involves focusing on the conse. quences of certain actions and often takes the form of "what if" questions, such as: "What if I make another. mistalke?" or "What if we lose the game?". "Thins atl. letes slould have more task-oriented thoughts rather than a preoccupation with thoughts of making mis. takes.

The appropriate attentional focus allows the atlilete to be acutely aware of his or her own body and the surrounding athletes. The athlete also has the sensation of being completely in harmony with the environment ${ }^{24}$.

Nideffer ${ }^{2 H}$ views attentional focus along two dimensions: width (broad versus narrow) and direction (internal versus external). These combine to give four different types of attentional focus. A broad attentional focus allows athletes to attend to several occurrences simultanconsly. This is essential in sports where athletes have to be aware of and sensitive to a rapidly changing environment and be able to respond to multiple cues (e.g. a hockey player leading a ball up the ficld). A narrow attentional focus is requited when atliletes have to attend to only onc or two cues (e.g. pistol shooting). An external attentional focts shifts attention ontward on an object, such as a ball or an opponcnt's movements (e.g. in a doubles tennis match). An internal attcntional focus is directed inward on thouglts and feclings (e.g. monitoring calf muscle tension).

Athletes must initially control the width of their attention and decide whether to exclude or include the many environmental cucs available during the competition. Furtlier, athletes nust be able to control the direction of their attention by eitler focussing inwards on their own feelings, thoughts and arousal level or focusing on external cues such as the opponent or ball. Athletes should ideally be able to change their focus of attention in accordance with the changing attentional demands during conpetition.

\section{Scll-talk}

Self-verbalizations, expressed aloud or as thoughts, have a strong impact on a person's beliaviour: 'The actual words used by athletes during self-talk influence the level of performance. Performance levels of elite ath. letes can be improved throtigh thought processes and thought content alone without increased physiological efforts or energy costs."

Self-talk can be positive or negative. Positive self-tall enlanecs tlie selfesteem, motivation, attentional focus and performance of athletes. Self-talk that lielps athletes focus on the present and prevents their mind from wandering is vicwed as positive. It usually has eitler a motivational conponent (e.g. "I can do it") or an instructional component (e.g. "Keep your eyes on the ball"). On the otlıer lıand, negative self-talk is critical and demeaning and impairs the realization of goals. Negative sell-talk (c.g. "That was a stıpid 111istake") creates anxicty and self-doubt. ${ }^{\text {N.27 }}$

Thouglits play a crucial role in mediating emotional reactions to situations, and these reactions influence future behaviour. Events in and of themselves do not cause negative emotional reactions (e.g. depression, anger, auxiety, hopelessness or (rustration). Rather it is how atliletes interpret the event that deternines their response. ${ }^{\mathrm{H}}$

Sclf-talk niay be used by atliletes to accutinc new skills, cliange bad habits, initiate action (c.g. riwners can increase their speed by using cue words such as "fast") and sustain effort when the athlete feels tired (c.g "keep it up", "llang in there"). "

Several techniques can be used to improve self-talk. One strategy to deal with negative thonglits is to stop them before they impair performance. Athletes are trained to stop negative thouglits as soon as they arise by using a cue word (such as "stop") or any pliysical trigger (such as suapping fingers or hitting a hand against a thigh) and then focus on a task-related cue. ${ }^{8.27}$

It is lowever not possible to elininate all negative self-talk. Another way to deal with negative self-talk when it occurs, is to cliange the negative thouglits into positive thoughts, which refocuses the athlete's attention to provide encouragencent and motivation and which brings the athlete back into the present to take control of the event. For example, "I never play well when the wind blows" can be rephrased into "Nobody likes to play in windy conditions, but I will perform at my personal best" $x=7$

Cue words can also be used to set in motion a specific response. They can be used as an instruction (e.g. "follow-through", "watell the ball") or to motivate (e.g "strong", "relax", "get tough"). The cue word slionld be simple and should antomatically trigger the planned reaction. For example, gymmasts performing a floor routine can say the word "forward" to cusure that they push alead at a specific point diuring their rontine. Sprinters can say "explode" to ensure that they get ont of the starting block quickly. Atliletes must practice using these cue words so that they becone labitual and well-leaned before being utilized during conpetition. Cue words are helpfid when athletes are trying to change a movement sequence or when trying to change an ingrained labit." 


\section{High self:confidence}

Atliletes' performance is enlanced as their level of selfconfidence increases - up to an optimal point - alter which futture increases in self-confidence result in impairment of performance.

Atlletes lacking self-confidence doubt their capability to perform the skills under presst1re during the competition. Self-doubts hinder atliletes' performauce by causing anxiety, reducing concentration and creating indecisiveness. Athletes lacking self-confidence focus on their weaknesses ratlier than on their strong points and distract their attention away from the task that has to be completed. On the other hand, the performance of athletes who are overconfident (their confidence is greater that their abilities justify) may deteriorate because they think that they do not have to prepare themselves for the event or expend the effort to consplete the task."

Athletes with optinual self-confidence are characterised by a positive attitude and feelings of optimism. ${ }^{26}$ They are able to keep poise and feelings of strength aud control even during adversity or potentially threatening situations. The athletes are in control of their actions and of the environment." The performance secms to be automatic and effortless.

Many potential benefits for atlletes arise from a feeling of high self-confidence. Confident athletes are morc likely to stay calm and relaxed under pressure. Confidence facilitates concentration so that the athletes can focus on the task at liand. Confident atlletes tend to set challenging goals and pursue them actively and witl increased vigour. Confident athletes tend to play to win and are usually not afraid to take cliances. Confidence helps athletes deal more effectively with crrors and mistakes.

\section{Goal-setting}

A good method to improve athletes' confidence is to set effective goals that provide direction and enlance motivation. ${ }^{\circ}$ It is important that athletes understand the difference between outcome goals and performance goals. Outcome goals stress the competitive result of an event, stich as wimning a competition or gane. Athletes with this orientation are concerned about wimning or losing rather than thinking about the quality of their performance. Achieving outcome goals therefore depends not only on the athletes' own cfforts but also on the abilities and performance of their opponents. Outcome goals are therefore connter-productive, because they often empliasize aspects that cannot be controlled by the ath. letes (especially in team sports). When atliletes are too concerned about outcome goals, this catuses anxiety during competition, and the athletes worry unnecessarily instead of concentrating on the task. On the other hand, performance goals focts on realizing performance objectives that are compared with the atliletes' own previous performance and therefore do not focts on the ontcome of the event.

Goal setting is a very good metlod for improving athletes' performance if implemented correctly. In order to promote beliavioural cliange, goals must be specificd in a measurable way and in beliavioural terms. In order to be effective, goals must be set difficult culough to chal- lenge the atliletes, yet realistic enough to be achievable. Short-term goals should be used as a method to achicve long-term goals and should be recorded and kept in a visible place.

Strategies or plius must be ontlined to achicve the goals that have been set. Atliletes must be part of the goal settiug process which needs to be constantly monitored and evaluated. Regular performanec fecdback and support from significant others is important if goalsetting is to be effective.

\section{Imagery}

The terms mental practice, inngery, visnalisation and mental relicarsal are nsed interchangeably to relate an athlete's mental preparation for competition. Imagery is the use of visualization to imagine situations. Internal inagery malkes it possible for athletes to kinesthetically experience the corrcet execntion of a skill, while external imagery lets them see themselves performing the skill."

Athletes can use imagery to recreate past expericnces or visualize future new events to ready themselves nentally for performance. When using imagery, the atlilete needs to involve as many senses as possible in order to create life-like images. It is also important to gencrate the cmotions or moods associated witl specific tasks or slrills that are being imagincd.

Athletes should pay attention to curironnental detail (e.g. layout of the facilities, closeness to spectators) and recreate the atmosplicre of the actual competition. Mauy Olympic teams visit the actnal competition sites montlis in advance to familiarize themselves with the sturoundings so that they can risualize themselves performing in that exact setting, with its specific colour, layont, lighting and constrnction.

Athletes cau ne imagery to improve botli pliysical and psychological slcills. Concentration nay be cullanced by atlletes imagining themselves in silitations where they generally lose concentration and then visualizing themselves rematining composed and focused. Inagery can be nsed to binild confidence in athletes. 'They can inagine situations that have caused problems in the past aud then picture thenselves coping positively with these events. The best-known use of imagery is practising particular sport skills in detail (c.g. throwing a javelin) repetitively to hue tunc them or identify wealuesses and visnalize correcting them.

For inngery to be incisive, it needs to be practised as part and parcel of an atlilete's daily rontine. At the beginning, it is best to practise in a setting with no distractions. With practice, atliletes learn to nse imagery anid distractions and even in actual competitions. The tine spent imagining a particular skill shonld eventual. ly be equal to the time the slitl actinally takes to ocem in order to injorove the transfer Grom imagery to real life situations.

\section{DEIERMINATION, COMMITMENT AND CONTROL}

Determination, commitment and self-control have been recognized as key psychological ingredients for sporting excellence. excellence withont complenentary ligh levels of per- 
sonal determination and commitment. Achieving the ultimate standard possible requires an athlete to make sacrifices: to train harder and longer, to expend more time and effort during practices. ${ }^{1}$ Orlick and Partington $^{31}$ stated that for the most successful Canadian Olympic athletes at the 1984 Olympics exce1lence in sport was the top priority in their lives: every. thing revolved around their sport. They were complete. 1y committed athletes with clearly defined success goals. The emphasis was on quality training, bolstered by pre-set individualized training goals and a clear commitment to follow their plans.

To achieve real athletic success, maturity and selfcontrol are essential. Being able to react effectively in big games and tight situations as well as in normal games requires confidence and composure.

\section{CONCLUSION}

Refining and perfecting mental skills takes life-long practice. ${ }^{16}$ It is a tedions, tinie-consuming effort. Just as physical training is. Only a sclect few will bring all components together consistently. They are the elite. Yet each and every athlete can learn, apply and grow through the inclusion of psychological skills training in their athletic life, at whichever level they choose to compete. For those at the top the choice is clear. Psychological skills training is a must to be part of the Olympic experience. To be part of the experience of excellence.

Reflecting on the sport psychology services provided to the US team at the 1988 Summer Olympics in Seoul, Murphy and Ferrante" concluded: "At a moment when the whole world seemed focused on winning versis losing, we became even more committed to our basic plilosoplyy of helping each individual learn and grow as a function of his/her Olympic experience".

\section{REFERENCES}

1. Williams JM. Psychological characteristics of peak performance.In: Willians JM, ed., Applied Sport Psychology: Personal Growth to Peak Performance. Palo Alto, California:Mayfield Publishing Company, 1986: 123.132.

2. Van-den Awweele $Y$, De Cuyper B, Van Mele V, Rzewnicki $R$. Elite performance and personality: From description and prediction to diagnosis and intervention. In: Singer; RN. Murphey, M., Tennant, LK., eds., Handbook of Research on Sport Psychology. New York: MacMillan Publishing Company, 1993:257-289.

3. Rushall, BS. Sport psychology: The key to sporting excel. lence. International Journal of Sport Psychology, 1989; 20(3): $165-190$.

4. Gould D. Eklund RC, Jackson SA. 1988 US. Olympic wrestling excellence: $I$. Mental preparation, precompetitive cognition, and affect. The Sport Psychologist, 1992; 6: 358 $-382$.

5. Gould D, Eklund RC, Jackson. SA. 1988 U.S. Olympic wrestling excellence: II. Thoughts and affect occurring during competition. The Sport Psychologist, 1992;6:383 $-402$.

6. Landers, DM., Boutcher, SH. Arousal-performance relationships. In: Willians, JM., ed., Applied Sport Psychology: Personal Growth to Peak Performance. Palo Alto, Califonia:Mayfield Publishing Company, 1986: 163-184.

7. Vealey RS. Personality and sport: $A$ comprehensive view. In: Horn TS., ed. Advances in Sport Psychology. Champaign, Illinois: Human Kinetics Publishers, 1992: 25-60.
8. Weinherg RS, Gould D. Foundations of Sport and Exercise Psychology. Champaign. Illinois:Human Kinetics, 1995.

9. Touferis A. Engineering the perfect athlete. Time 1992; Jthly: $46-51$

10. Williams JM. Integrating and implementing a psychological skills training programme. In: Williams JM.. ed. Applied Sport Psychology: Personal Growth to Peak Performance. Palo Alto, California: Mayfield Publishing Company, 1986, 301-324.

11. Gould D. Murphy S. Tammen V. May J. An evaluation of US Olympic sport psychology consultant effectiveness. The Sport Psychologist 1991; 5: 111-127.

12. Nideffer RM. Psychological services for the US track and field team. The Sport Psychologist 1989; 3: 350-357.

13. Partington $J$, Orlick T. An analysis of Olympic sport psychology consultants' best-ever consulting experiences. The Sport Psychologist 1991; 5: 183-193.

14. Gould D. Eklund RC, Jackson SA. Coping strategies used by US Olympic wrestlers. Research Quarterly for Exercise and Sport 1993: 64 (1): 83-93.

15. Nowichi $D$. Using mental training during residential squad training in combat sports: A Polish experience. The Sport Psychologist 1995; 9: 164-168.

16. Orlick T. Reflections on sportpsych consulting with individual and team sport athletes at Stummer and Winter Olympic Games. The Sport Psychologist 1989, 3: 358-365.

17. Gipson M. McKenzie T, Lowe S. The sport psychology programme of the USA women's national volleyball team. The Sport Psychologist 1989;3:330-339.

18. Gordin RD, Henschen KP. Preparing the USA women's artistic gymnastics team for the 1988 Olympics: A multimodal approach. The Sport Psychologist 1989: 3: 366-373.

19. Halliwell W. Delivering sport psychology services to the Canadian sailing team at the 1988 Summer Olympic Games. The Sport Psychologist 1989; 3: 313-319.

20. Kirschenbaum DS. Parham WD. Murphy SM. Provision of sport psychology services at Olympic events: The 1991 US Olympic festival and beyond. The Sport Psychologist 1993; 7: 419-440.

21. Suinu RM. The 1984 Olympics and sport psychology. Journal of Sport Psychology 1985; 7: 321-320.

22. Salmela JH. Long-term intervention with the Canadian men's Olympic gymnastic team. The Sport Psychologist 1989; 3: 340-349.

23. May JR. Brown L. Delivery of psychological services to the US alpine ski team prior to and during the Olympics in Calgary. The Sport Psychologist 1989: 3: 320-329.

24. Gould D, Krane V. The arousal-athletic perfornance relationship: Current status and future directions. In: Horn TS, ed. Advances in Sport Psychology. Champaign. Illinois: Human Kinetics Publishers, 1902: 119.142.

25. Loehr JE. How to overcome stress and play at your peak all the time. Tennis 1984; March: 66-76.

26. Garfield CA, Bennett IIZ. Peak Performance:Mental Training Techniques of the Whild's Greatest Athletes. Los Angeles: Tarcher, 1984.

27. Schomer HH. Psychological training techniques for athletes. In: Potgieter JR. ed. Readings in Sport Psychology. University of Stellenbosch:Institute for Sport and Movement Studies, 1992; 1-11.

28. Nideffer RM. Athletes' Guide to Mental Training. Champaign, Illinois: Human Kinetics Publishers. 1985.

29. Cox RH. Sport Psychology: Concepts and Applications. 3rd Edition: Dubuque, lowa: Brown \& Benchmark: 1994.

30. Orlick T. In Pursuit of Excellence. Champaign. Illinois:Human Kinetics, 1980.

31. Orlick T, Partington J. Mental links to excellence. The Sport Psychologist 1988; 2: 105-130.

32. Murphy SM, Ferrante AP. Provision of sport psychology services to the US team at the 1988 Stummer Olympic Games. The Sport Psychologist 1989: 3: 374-385. 


\section{National Olympic Committee of South Africa (NOCSA) \\ Anti-doping Policy \\ April 1996}

\section{Dr G Ruijsch van Dugteren MB ChB FCP}

\section{INTERPRETATION}

In this policy, the following words have the following respective meanings:

"NOCSA" the National Olympic Committee of
South Africa.

"WDS" the Institute for Drug-Free Sport

"Agency" any agency throughout the world recognised by NOCSA as conducting sampling or testing, or both, of athletes for the detection of doping and in accordance witll the IOC Medical Code;

"NSC" the National Sports Council

"Athlete" (a) a member or potctitial member of a South African Olynupic Team;

(b) a member of a NOCSA Affiliate or person competing in any competition under the control or auspices of a NOCSA Affiliate;

(c) a person competing in any competition in South Africa contested in the framework of the Olympic Movement, in particular those competitions organised under the authority, whether direct or delegat$e d$, of an International Federation, NOCSA or a NOCSA Affiliate.

"Doping" is defined as:

(a) the administration of substances belonging to prohibited classes of pliarmacological agents; and/or

(b) the use of various proluibited methods

as described in Chapter II of the IOC Medical Code (as in force from time to time).

"FF"

an International Federation being a body controlling a brancl of sport and recog. nised as such by the IOC.

"IOC" the International Olympic Committec, being an association created by the Congress of Paris of 23 June 1984 and which is entrusted with the control and development of the modern Olympic Games pursuant to the Olympic Cliarter.
"IOC the Medical Code provided for under Medical Code" Rule 48 of the Olympic Charter.

"Atfiliate" any Body which is affiliated to NOCSA.

"Olympic the Olympic Charter of the IOC Charter" or any amendnent, modification or replacenient thereof.

"Responsible the IOC, IFs, NOCSA, NSC, DD, NFs and Autlıority" NOCSA Affiliates.

Trafficking occurs when any person:

(a) manufactures, extracts, trausforms, prepares, stores, expedites, transports, imports, transits, offers (subject to payment or free of cliarge), distributes, sells, exclianges, brolkers, obtains in any forn, prescribes, commercialises, malses over; accepts, possesses, holds, luys or acquires in any manncr products or substances which are prohibited under the IOC Medical Code;

(b) acts in this respect, finances or: serves as an intermediary for the financing of the latter, provoles in any way the constumption or use of sucl products or pro. hibited substances or establislies means of procuring or consuming sticli substances; or

(c) is concerned or involved in metlods which are prolubited by the IOC Medical Code, other than in the conrse of the legal cxercise of professional activities.

Any words when used in the plural shall have a corresponding neaning in the singular.

Any words nsed in the masculine gender shall have a corresponding meaning in the feminine gender.

Words not defined in this policy shall have the meaning ascribed to them in the Constitution of NOCSA unless a contrary meaning appears from the context.

\section{POSITION STATEMENT.}

2.1 The IOC's Medical Code (Olympic Cliarter Rule 48) (i) provides for the prolibition of doping, (ii) determines the classes of prolnibited substances and prolubited netliods, (iii) establishes the list of accredited laboratories, (iv) pro- 
vides for the obligation of competitors to submit themselves to medical controls and examinations, (v) lays down testing procedures, including procedures for selection of athletes, sample collection and sample analysis, (vi) provides for appeals to the Court of Arbitration for Sports, (vii) determines sanctions to be applied in the event of a doping violation and (viii) prolibits the trafficking in prohibited substances.

2.2 On 13 Jamiary 1994 representatives of the IOC, the Association of Summer Olympic International Federations, the Association of International Winter Federations, IFs, the Association of National Olympic Committees, the continental associations of NOCs and athletes agreed, anong other things:

(1) to unify their anti-doping rules and procedures for the doping controls performed both during and out of competition;

(2) to adopt, each ycar, as a basic doctument the list of prohibited classes and methods of doping established by the IOC Medical Commission and to undertake the necessary controls for each sport;

(3) to accelerate unification of the minimum sanctions provided for by the IOC Medical Commission for violations of the anti-doping regulations and to ensure their application at both international and national level;

(4) to recognise the sanctions imposed by an IF;

(5) to use laboratories accredited by the IOC for all international competitions and out of competition testing; and

(6) to develop co-operation between the IOC, IFs, NOCs, National Federations and governments or other organisations concerned in order to organise and carry out doping controls and to combat the trafficling of prolibited substances in sport.

2.3 The IOC Medical Code and this policy are essentially intended to safeguard the health of athletes and to cnsture respect for the ethical concepts implicit in Fair Play, the Olympic Spirit and medical practice.

\subsection{Doping is proluibited}

2.5 All athletes must provide samples for testing at the request of a Responsible Authority or Agency.

2.6 The counselling of the use of, permitting the use of, or condoning the use of any substance or method contrary to the IOC Medical Code is prohibited.

\section{APPLICATION OF ANTI-DOPING POLICY}

3.1 This policy applies to:
(1) athletes, whether in or out of competition;

(2) coaches, trainers, officials, and medical and paramedical personuel working with or treating atliletes;

(3) NOCSA Affiliates; and

(4) all persons involved in trafficling.

3.2 Sanctions are applicable in the event of any breach of the provisions of this policy.

\section{DOPE 'TESTING}

4.1 NOCSA or an Agency may conduct sampling and testing or both of athletes for the detection of doping.

4.2 A Responsible Autliority may select an atluete to provide any number of samples for dope testing in a year, whether in or out of competition.

4.3 Sampling and testing of atliletes nunst be conducted in conformity with the IOC Medical Code.

4.4 Minor irregularities which camot reasonably be considered to affect the results of otherwise valid tests, will not invalidate such results. However, tests may be invalidated in the case of serious irregularities such as a break in the cliain of custody of the sample, improper scaling of the container in which the sample is stored, failure to request the signature of the athlete, or failure to provide the athlete with an opportunity to be present or be represented at the opening and analysis of the "B" sample.

4.5 Every NOCSA Affiliate must:

(1) permit NOCSA or an Agency to attend contpetitions conducted by it, or nunder it's anspices, in order to obtain samples for dope testing;

(2) permit NOCSA or an Agency to obtain samples for testing from athletes out of competition and provide reasonable assistance for this purpose.

(3) inform atlletes that they are liable for selection to provide samples for dope testing whether in Soutl Africa or overseas;

(4) arrange for completion and return of forms required for dope testing putposes at the request of NOCSA, an Agency or a Responsible Authority;

(5) require and cause athletes and officials to permit NOCSA or an Agency to collect samples for testing out of competition and provide reasonable assistance for this purpose;

(6) use NOCSA or an Agency to conduct any additional test required by the NOCSA Affiliate 
in South Africa at its own expense;

(7) submit its anti-doping policy to NOCSA for approval of consistency with its policy and there. after not alter or amend its approved anti-doping policy witlout first obtaining the approval of NOCSA.

\section{OTHER DOPING OFFENCES}

5.1 Should an athlete fail or refuse to provide a sample upon request, then this will be an infraction of this policy and for which the athlete is subject to the same penalty as if the athlete had committed doping.

5.2 Where an athlete has made a statement admitting doping such statement will be prima facie evidence of an infraction of this policy. Upon notification of such a statement, the Secretary -General may conduct enquiries as he or slie deems appropriate to determine whether there is sufficient evidence that the statement of admission of doping was made. In conducting these enquiries, NOCSA will not be obliged to conduct any hearing or to receive any evidence or statements by or on belialf of the atlilete concerned.

5.3 Should a NOCSA Affiliate fail to adopt and implencnt an anti-doping policy consistent with this policy, it will be in breach of NOCSA's Constitution and this policy and liable for the penalties described therein for a breach of the Constitution or By-Laws made thereunder.

5.4 Trafficking is prohibited and any person (including any body, corporate or unincorporate) involved in trafficking is liable to sanction under this policy.

5.5 Any person will be deemed to be involved in traffickling if that person:

(1) has aided, abetted, counselled or procured the trafficking;

(2) has indtuced, whether by threats or promises or otherwise, the trafficking;

(3) has been in any way, directly or indirectly, knowingly concerned in, or party to, the trafficking; or

(4) has conspired with others to effect the trafficking.

5.6 Clauses $\mathbf{5 . 4}$ and $\mathbf{5 . 5}$ do not apply to doctors, pliarmacists and other nembers of the medical profession or holders of analogous diplomas recognised by the public anthorities concerned, when one or other of the above clauses is necessary for them within the strict limits of exercising the art of healing.

\section{ADVICE OF ALLEGED BREACH}

6.1 Where NOCSA has requested an Agency or Agencics to conduct sampling or testing or both of athletes, that Agency or Agencies will notify NOCSA of the names and results of any athlete who retumed a positive test result or who failed to comply with the requirement to provide a sample for testing.

6.2 Affiliates must notify NOCSA of the names and result of any athlete who returned a positive test result or who failed to comply with a requirement to provide a sample for testing. Other Responsible Authorities may so notify NOCSA.

6.3 Atlletes and Affiliates must notify NOCSA of the names of any person who they know or reasonably suspect of being involved in trafficking, and must provide NOCSA with all such information and assistance as they are able to give to enable NOCSA to conduct an investigation into the circumstances surrounding the suspected trafficking. Failute to do so will be considered trafficking by the athlete or NOCSA Affiliate conceriled.

6.4 NOCSA will maintain confidentiality of information provicled 1mder clauses $6.1,6.2$, and 6.3 1witil after a decision (if any) to impose a sanction for a breach of this policy has been deterninined except as is necessary to conduct or prosecute any learing under this policy or to notify the relevant Responsible Authorities.

\section{NOTIFICATION OF ALLEGED BREACH BY AN ATHLETE OR OTHER PERSON}

7.1 Where NOCSA receives notification from an Agency or a Responsible Anthority that an atlilete lias retwined a positive test result or has failed to comply with a request to provide a sample or for another reason believes that a person to whom this policy applies has commitited an infraction of this policy, NOCSA will give to the atlilete or person concerned notice of the alleged infraction.

7.2 This notice of alleged infraction (clause 7.1 above) inutst:

(1) be in writing and be delivered to the athlete or persoll;

(2) set out the nature and particulars of the alleged infraction;

(3) set out or enclose an extract of this policy relating to the sanctions that may be imposed if it is determined that the alleged infraction has occurred, and

(4) state that a Hearing to decide whether an infraction of this policy has occurred and what penalty to impose will be determined by a 
Comnittee appointed by the IDS according to the procedures described in clause 9.

\section{OLYMPIC GAMES}

8.1 The IOC Executive Board is the only body competent to rule on the effects of a positive test restult during the Olympic Games.

8.2 Should an athlete be found by the IOC Executive Board to have conmuitted doping during the Olympic Games, any liearing by a Conmittee appointed by NOCSA or any appeal therefrom to the Court of Arbitration for Sport will be bound by that finding and the hearing or appeal will be linnited to the sanction to be imposed for the breach of this policy.

\section{PROCEDURE FOR THE CONDUCT OF HEARING INTO DOPING}

9.1 Where NOCSA gives an athlete or person a notice pursuant to clause 7, NOCSA will consult with the Affiliate of the atllete or person concerned with a view to there being a joint hearing on behalf of NOCSA and the Affiliate to determine:

(1) whether the atlulete or person lias committed an infraction of this policy and/or the antidoping policy of the NOCSA Affiliate;

(2) what sanction consistent with this policy should be applied to the athlete or person who was found to have committed an infraction of this policy.

9.2 Should it not be possible or feasible to conduct a joint liearing pursuant to clause 9.1, the liearing will be on behalf of NOCSA alone.

9.3 The NOCSA Executive will appoint a Committee of up to three persons to conduct a hearing.

9.4 The Conmittee may conduct a liearing in such a manner as it determines. Hearings nay be conducted by telephone or other conference facilities.

9.5 Hearings are to be conducted with as little formality and technicality, and with as much expedition, as proper consideration of the matter before the Committee permits.

9.6 At a hearing of the Committee:

(1) the Committee may examine and cross exanime witnesses and may appoint a legal representative or other person to assist it;

(2) NOCSA and, if the hearing is a joint hearing on behalf of NOCSA and an Affiliate, that Affiliate, may separately or jointly exantine and cross-examinc witnesses and be assisted by legal representation or other person;
(3) the athlete or person concened may examine and cross-exanine wilnesses and may be assisted by a legal representative or other person; and

(4) where an athlete contends that sampling or testing or botli of him or her is not substantially in conformity with the IOC Medical Code, the onus shall be on the atlilete to show on the balance of probabilities that his or her contention is correct and that as a result thicreof the results of the sampling and testing have been so affected as to not record doping.

9.7 The Committee will make a statement in witing stating its findings of fact and its decision and will send the statement to NOCSA. The Committee is not bound to give a statement of its reasons for its decision.

9.8 NOCSA will send a copy of the statement to:
(1) the IOC
(2) the IDS
(3) the NSC

(4) the Affiliate of which the athlete or person is a nienber; and

(5) any other person or organisation that NOCSA believes should be inlonned.

9.9 The Committee will send to the atlilete or person concened a copy of the statement so far as it relates to the athlete or person, but the athlete or person is not entitled to a copy of the Committee's statement of its reasons (if any).

\section{APPEAIS}

10.1 An atllete or person who is dissatisfied with a decision made in relation to him or her under this policy may, within 14 days of receiving written notification of the sanction imposed, appeal to the Court of Arbitration for Sport and request that an appeal be conducted in relation to:

(1) the determination that an infraction of this policy has occurred and the imposition of the sauction; or

(2) the sanction that has been imposed.

10.2 Any such appeal will be conducted according to the Code of Sports-Related Arbitration.

10.3 An appeal deals only with the original matters appealed against.

10.4 Upon receiving notice of the outcone of an appeal from the Court of Arbitration for Sport, NOCSA will give written notice of the outcome to: 
(1) the athlete or person malking the appeal; and

(2) the persons and/or organisations provided with the statement pursuant to clause 9.7 .

10.5 An appeal conducted in accordance with this policy is the sole form of appeal from the decision under this policy. No appeal may be made to a contt or other tribunal.

\section{SANCTIONS}

11.1 Any athlete who is found to have committed doping will be ineligible for memberslip of or selection in any South African Olympic Team, or to receive finding from or to hold any position on NOCSA as follows:

(1) for a first infraction other than cases provided for in paragraph (2) - suspension for two years.

(2) for a first infraction in cases of a positive result for epliedrine, plicnylpropanolaniuc, psendo-ephedrine, caffeine, strychnine and related conpounds - suspension for a maximum period of three months;

(3) for the second offence other than in the cases provided in paragrapl (4) - suspension for his or her lifetime;

(4) for a second infraction in cases of a positive result for ephedrine, phenylpropanolanine, pseudo-ephedrine, caffeine, strychnine and related compounds - suspension for two years.

(5) for a subsequent infraction in cases of a positive result for epliedrine, plienylpropanolamine, psendo-epliedrine, caffeine, stryclunine and related compounds - suspension for his or her lifetime.

11.2 Where an athlete or other person to whom this policy applies is found to have committed an infraction of this policy other than doping lie or she will be subject to at least the same penalties as described in clause 11.1, provided that sucl penalties are a minimum only and may be increased according to the circumstances and culpability involved.

11.3 The above sanctions may be applied to a person regardless of any sanction or penalty, its duration or timing or whether current or past, imposed by any Responsible Authority PROVWED THA'l NOCSA will recognise previous sanctions imposed by any Responsible Authority to determine whether the breach is a first or second offence.

11.4 NOCSA will, however, recognise sanctions imposed by a relevant IF if its sanctions extend for a longer period than that imposed by NOCSA.
11.5 Failure by an invited atlulete or person to attend to be heard by the Committee in accordance with clatuse 9 for whatever reason will not invalidate the right of NOCSA to inrpose a sanction in accordance with this policy.

\section{PRESS RELEASE}

A press release may be issued by NOCSA in relation to any sanction imposed under this policy.

\section{REVIEW OF SANCTION}

13.1 Where an athlete or person to whom a sanction has been applied under this policy has new and relevant information concerning the infraction, he or sle or it nua ruake written application to NOCSA setting out the grounds for a possible review of that sanction. The Executive of NOCSA may consider the application and determine in its sole and absolute discretion to either:

(a) itself review any sanction imposed tunder this policy and whether to alter a decision made previously including a reduction or withdrawal of the sanction; or

(b) refer the matter to the Court of Arbitration for Sport for that Court to determine whether to review any sanction imposed under this policy and whether to alter a decision made previously including a reduction or vithdrawal of the sanctiou.

13.2 NOCSA will not alter any decision under clause 13.1 without lirst consulting with any otler sports organisation which it knows has a current sanction over the athlete or person and obtains its agreenent to the alteratiou.

13.3 Notification of any change to the previous decision will be made in accordance with clatse 11.

\section{EDUCATION AND OTHER INITIATIVES}

NOCSA will indertake the following anti-doping initiatives:

(1) Support the anti-doping policies of the Goveriment througl the Listitute for Drug-Free. Sport.

(2) Encourage the development and iniplementation by Responsible Authorities of drug education programmes for atliletes and officials.

(3) Support the information and edncational initiatives of Responsible Autlorities. 


\title{
South African Institute for Drug-Free Sport
}

\section{INTERNATIONAL OLYMPIC COMMITTEE MEDICAL COMMISSION}

\author{
Prohibited Classes of Substances and Prohibited Methods \\ January 1996
}

Doping contravenes the ethics of sport and medical science.

Doping consists of:

1. the administration of substances belonging to selected classes of pharmacological agents, and/or

2. The use of various prohibited methods.

\section{PROHIBITED CLASSES OF SUBSTANCES}
A. Stimulants
B. Narcotics
C. Anabolic Agents
D. Diuretics
E. Peptide and glycoprotein hormones and ana- logues

\section{PROHIBITED METHODS}
A. Blood doping
B. Pharmacological, chemical and physical manipu- lation

\section{CLASSES OF DRUGS SUBJECT TO CERTAIN RESTRICTIONS}
A. Alcohol
B. Marijuana
C. Local anaesthetics
D. Corticosteroids
E. Beta-blockers

\section{EXAMPLES AND EXPLANATIONS}

This document lists examples representing different doping classes to illustrate the doping definition. No substances belonging to the banned classes may be used even if they are not listed as examples. For this reason, the term "and related substances" is introduced. This term describes drugs that are related to the class by their pharmacological actions or chemical structure. A longer list of examples belonging to different pharmacological classes of banned substances can be found in anuex 1 .

If substances of the banned classes are identified by an IOC accredited laboratory the relevant authority will act.

\section{PROHIBITED CLASSES OF SUBSTANCES}

\section{A. Stimulants}

Stimulants comprise various types of substances which increase alertness, reduce fatigue and may increase competitiveness and lostility. Their use can also produce loss of judgement, which may lead to accidents to others in some sports. Amfetamine and related compounds have the most notorious reputation in producing problems in sport. Some deaths of sportsmen have restulted even when normal doses have been used under conditions of maximum plyssical activity. There is 110

medical justification for the use of "amplictamines" in sport.

One group of stimulants is the sympathomimetic amines of which epliedrine, psendoepliedrine, plienylpropanolamine and norpseudoepliedrinc are examples. In ligh doses, this type of compound produces mental stimulation and increased blood flow. Adverse effects inclucle elcvated blood pressure and lieadache, increased and irregular heart beat, anxiety and tremor. These compounds are often present in cold and hay fever preparations which cau be purchased "over the counter" fiom pharmacies and sometimes from other retail outlets without medical prescription.

Another group of stimulants is the beta-2 agonists. These drugs are unusual becatuse they are classified as both stimulants and anabolic agents. When taken by montl or by injection they may exert powerful stimulatory and anabolic effects. Oral and injectable administration of beta-2 agonists is banned.

Of the beta-2 agonists only Salbutanol, Salmeterol and Terbutaline are pernutted and only by inlıalation. Any physician wishing to administer beta- 2 agonists by inhalation must give written notification to the relevant medical antliority prior to the competition.

The choice of medications to treat asthma and other common respiratory disorders poses a problem because some of the more commonly prescribed stibstances are powerful stimulauts. Furthermore, because tliese drugs have many different product names, the status of a diug may be confusing. Thie most prudent approach is never: to take or prescribe a product for colds, sore throats, and flı without fìst clıecking with a physician or pharmacist who has special expertise in this area.

Prohibited substances in class (A) include the following examples:

amiphenazole

amineptine

cocaine

fencanfamine

pentylentetrazol

salbutanol *

salmeterol **

amplietamines

caffeine *

ephedrines

niesocarb

pipradol

terbutaline * *

... and related substances.

* Caffeine: The definition of a positive depends on the concentration of caffeine in the urine. The concentration in urine nay not exceed 12 micrograns per: milliliter.

* * Salbutamol, salmeterol and terbutaline are permitted by inhaler only and must be declared in writing, prior to the competition to the relevant medical authority.

NOTE: All inuidazole preparations are acceptable for topical use, e.g. oxymetazoline. Vasoconstrictors (e.g. adrenaline) may be administered with local anaesthet- 
ic agents. Topical preparations (e.g. nasal, ophthalnological) of phenylephrine are permitted.

\section{B. Narcotics}

Morpline and other compounds of this class are powerful analgesics and are mainly used for the management of severe pain. These stbstances liave major side effects, including respiratory depression, and they carry a high risk of physical and psycloological dependence. Evidence reveals that narcotic analgesics have been abused in sports. Therefore the IOC Medical Commission has issued and maintained a ban on their use. The ban is consistent with international restrictions and with the regulations and recommendations of the World Health Organisation regarding narcotics.

Prohibited substances in class (B) include the following examples:

dextromoranide

diamorphine (heroin)

morphine

\section{dextropropoxyphene}

methadone

pentazocine

pethidine

... and related substances

NOTE: Codeine, dextromethorphan, dilydrocodeine, diphenoxylate and pholcodine are permitted.

\section{Anabolic agents}

The Anabolic class includes anabolic androgenic steroids (AAS) and Beta-2 agonists.

\section{Anabolic androgenic steroids (AAS)}

The AAS class includes testosterone and substances that are related in structure and activity to it. They have been misused in sport to increase muscle strength aud bulk, and to promote aggressiveness. The use of AAS is associated with adverse effects on the liver, skin, cardiovascular and endocrine systems. They can promote the growth of tumours and induce psychiatric syndromes.

In males AAS decrease the size of the testes and diminish sperm production. Females experience masculinization, loss of breast tissue and diminished menstruation. The use of AAS by teenagers can stiunt growth.

Prohibited substances in class (C1) include the following examples:

$\begin{array}{ll}\text { clostebol } & \text { fluoxymesterone } \\ \text { metandienone } & \text { metenolone } \\ \text { oxandrolone } & \text { oxandrolone } \\ \text { stanozolol } & \text { testosterone * } \\ \text {... and related substances }\end{array}$

* The administration of testosterone is banned.The presence of testosterone ( $\mathrm{T}$ ) to epitestosterone (E) ratio greater than six (6) to one (1) in the urine of a competitor constitutes an offence unless there is evidence that this ratio is due to a plyysiological or pathological condition, e.g. low epitestestosterone excretion, androgen production by tumour, enzyme deficiencies.

In the case of a $\mathrm{T} / \mathrm{E}$ ratio higher than 6 , it is mandatory that the responsible authority conduct an investigation before the sample is declared positive. A full report will be written and will include a review of previous tests, subsequent tests and any results of endocrine investigations. In the event that previous tests are not available, the atllete slould be tested unannounced at least once per montl for three montlis. Tlie results of these investigations sliould be included in the report. Failure to cooperate in the investigations will result in declauing the sample positive.

\section{Beta-2 agonists}

When given systemically, beta-2 agonists may have powerful anabolic effects, and their use is therefore banned. (See also section IA)

Prollibited substances in class (C 2) include the following examples:

clenbuterol

salbutamol

terbutaline

salmetcrol

fenoterol

$\ldots$ and related substances

\section{Dituretics}

Diuretics have inportant therapentic indications for the elimination of flude from the tissues in certain pathological conditions and for management of high blood pressure. Diuretics are sometimes misused by competitors for two main reasons, namely:

- to reduce weiglit quickly in sports where weight cat. egories are involved, and

- to reduce the concentration of substances by diluting the urine.

Rapid reduction of weight in sport cannot be justified medically. Health risks are involved in such misuse because of serious side-effects which might occur. Furthermore, deliberate attempts to reduce weight artificially in order to compete in lower weight classes or to dilute urine constitute clear manipulations which are tunacceptable on etlical grounds.

For sports involving weight classes, the responsible anthorities reserve the right to obtain urine samples from the competitor at the time of the weigh-in.

Prolibited substances in class (D) inclucle the following examples:

$\begin{array}{ll}\text { acetazolanide } & \text { bumetanide } \\ \text { chlortlalidone } & \text { cthacryinic acid } \\ \text { furosemide } & \text { hydrochlorothiazide } \\ \text { maunitol } & \text { mersalyl } \\ \text { spironolactone } & \text { triamterene } \\ \text {. . and related substances }\end{array}$

\section{E. Peptide and glycoprotein hormones and analogues}

Prolıibited substances iu class (E) include the following exaunples:

\section{Chorionic Gonadotrophin (HCG-human chori- onic gonadotrophin):}

It is well known that the administration to males of luman chorionic ganodotroph in (HCG) and other compounds witli related activity, leads to au increased rate of production of endogenous androgenic steroids and is considered equivalent to the cxogenons administration of testosterone. 


\section{Corticotrophin (ACTH):}

Corticotrophin las been misused to increase the blood levels of endogenous corticosteroids notably to obtain the euphoric effect of corticosteroids. The application of corticotrophin is considered to be equivalent to the oral, intra-muscular or intravenous adninistration of corticosteroids. (See section III. D).

\section{Growth hormone (HGH, somatotrophin):}

The misuse of growth hormone in sport is uncthical and dangerous because of various adverse effects, for exan1ple cardiomyopathy, hypertension, diabetes mellitus, and acromegaly when given in high doses for a long period of time. Contanuination of some growtl hormone preparations of human origin can cause Crentzfeldt Jacob disease (a fatal neurological condition).

NOTE: All the respective releasing factors of the abovementioned substances are also banned

\section{Erythropoietin (EPO):}

This naturally occurring hormone is produced in the kidney and regulates red blood cell production. Synthetic EPO is currently available and has been demonstrated to induce clianges similar to blood doping (sec $\Pi \mathrm{A})$.

\section{PROHIBITED METHODS}

The following procedures are proluibited:

\section{A. Blood doping}

Blood doping is the administration of blood, red blood cells or related products to au athlete. This procedure may be preceded by withdrawal of blood from the athlete who continues to train in this blood depleted state.

These procedures contravene the ethics of medicine and of sport. There are also risks involved in the transfusion of blood and related blood products. These include the development of allergic reactions (rash, fever etc.) and actute liacmolytic reaction with lichney damage if incorrectly typed blood is used, as well as delayed transfusion reaction resulting in fever and jaundice, transmission of infections diseases (viral liepatitis and AIDS), overload of the circulation and metabolic shock.

\section{B. Pharmacological, chemical and physical manipulation}

Pliarmacological, chenical and physical manipulation is the use of substances or of metlods which alter, attempt to alter or may reasonably be expected to alter the integrity and validity of urine samples used in doping controls. Examples of banned methods include, without limitation, catheterisation, urine substitution and/or tampering, inhibition of renal excretion such as by probenecid and related compounds, and epitestosterone administration.

The IOC Medical Commission bans the use of substances and of methods which alter the integrity and validity of turine samples used in doping controls.

If the epitestosterone concentration is greater than $200 \mathrm{ng} / \mathrm{ml}$, the laboratories should notify the appropriate anthorities. The IOC Medical Commission recommends that under these circumstances further investigations be conducted.

\section{CLASSES OF DRUGS SUBJECT TO CER'TAIN RESTRIC'IIONS}

\section{A. Alcohol}

In agreement with the International Sports Federations and the responsible anthorities, tests may be conducted for ethanol. The results may lead to sanctious.

\section{B. Marijuana}

In agreement with the International Sports Federations and the responsible anthorities, tests may be conductcd for cannabinoids (Marijuana, Dagga, Haslıislı . . .). The results may lead to sanctions.

\section{Local anaesthetics}

Injectable local auaesthetics are permitted iuder the following conditions:

a) that bupivacaine, liclocaine, nnepivacainc, procaine etc. are used but not cocaine. Vasoconstrictor agents (c.g. adrenaline) may be used in conjunction with local aracsthetics.

b) only local or intra-articular injections may be administered;

c) only when medically justified (i.e. the details including diagnosis, dose and ronte of administration must be submitted prior to the competition or immediately, if administered during the competition, in writing to the relevant medical a11thority).

\section{Corticosteroids}

Because of their anti-inflammatory properties, the nattually occiuring and synthetic corticostcroids are widely nsed in medicine to treat many discases. When administered systemically, they influcnee the natural production of corticosteroids by the body. Corticosteroids may produce mood changes including cuphoria and other side-effects such that their medical use, except when administered topically, demands medical control.

Because it was known that corticostcroids were being used non-therapentically in certain sports by the oral, rectal, intramuscular and even the intravenous routes, the IOC Medical Conmuission attempted to restrict their use during competitions by requiring a declaration by doctors. However, as such restrictions failed to solve the problem, stronger incasiues, designed not to interferc with the appropriate medical use of corticosteroids, became necessary.

The use of corticosteroids is banued except

a) for topical use (aural, opthahnological and dermatological, but not rectal;

b) by inhalation;

c) by intra-articulax or local injection The IOC has introduced mandatory reporting of athletes requiring corticosteroids by inhalation during competitions.

ANY TEAM DOCTOR WISHING TO ADMTNISITR CORTICOSTEROIDS BY LOCAL, OR INTRA-ARTICULAR INJECTION, OR BY INHALATION, TO A COMPETITOR MUST GIVE WRITTEN NO'TIFICATION 


\section{PRIOR TO THE COMPETITION TO THE RELEVANT} MEDICAL AUTHORITY.

\section{E. Beta-blockers}

Due to the continued misuse of beta-blockers in some sports the IOC Medical Commission reserves the right, at the Olympic Games, to test those sports which it deems appropriate. These are tudikely to include endurance events which necessitate prolonged periods of high cardiac output and large stores of metabolic substrates in which beta-blockers would severely decrease performance capacity.

In agreement with the rules of the Intenational Sports Federations, tests will be conducted in some sports at the discretion of the responsible authorities.

Some examples of beta-blockers are:
$\begin{array}{ll}\text { acebutalol } & \text { alprenolol } \\ \text { atenolol } & \text { labetalol } \\ \text { metoprolol } & \text { nadolol } \\ \text { oxprenolol } & \text { propranolol } \\ \text { sotalol } & \\ \ldots \text {. . and related substances. }\end{array}$

\section{EXPANDED LIST OF EXAMPLES: ANNEX I}

Cantion: This is not an exlanstive list of banned substances. It is provided only to give the reader a more comprehensive list of banned substances. Many substances that do not appear on this expanded list are considered banned under the term "and related substances".

\section{A. STIMULANTS}

anfepramone

amineptine

amfetamine

caffeine

cathine

cocaine

cropropamide

crotetanide

ephedrine

etamivan

etilamfetamine

etilefrine

fencamfamin

fenetylline

fenfluramine

heptaminol

medea

mefenorex

mephenterumine

mesocarb

metamfetamine mcthoxyphenamine methylephedrine nethylphenidate norplenfluamine

paralnydroxyamfctanine

pemoline

pliendimetrazine

plientcrmine

phenylephedrine

phenylpropanolamine

pholedrine

prolintane

propyllexed rine

pseudocplied rine

salbutamol

strychnine

B. NARCOTICS

dextropropoxyphene

cthylmorphine

lyydrocodone

morphine

pentazocine

pethidine

propoxyplene

\section{ANABOLIC AGENTS}

(1) Anabolic steroids

(2) BetaZ-agonists

boldenone

clenbuterol

clostebol

danazol

deliydroclilormethyl-

testosterone

dihydrotestosterone

drostanolone

fluoxymesterone

formebolone

mesterolone

metandienone

metenolone

methandriol

metliyltestosterone

nandrolone

norethandrolone

oxandrolone

oxymesterone

oxymetholone

stanozolol

testosterone

trenbolone

D. BETABLOCKERS

acebutolol

alprenolol

This information was kindly provided by the National Olympic Committee of South Africa

Some important points about over-thecomter medications and preseription drugs

1. Many atlletes purcliase from their local pharmacy over-the-counter medications for the treatment of c.g.lieadaclies, simusitis, liayfever, astlima, colds, influewza ete.

2. It is a known fact that the majority of the branded medications for treatment of the above ailments contain baumed substances, notably plenylpropanolamine and ephedrine.

3. An athlete should ask his/her pliamuacist or medical practitioner if a medication contains any banned substances before taking it.

4. An athlete should request his medical practitioner to complete a medical notification form whenever any drug is prescribed for treatment.

5. Remember that the accredited Drug Testing Iaboratory uses the most modenl and sensitive testing methods, and any atllete taking a banned substance will most certainly test positive even some' time after taking the substance. 


\title{
DOPING AND CLINICAL PRACTICE: ETHICAL PERSPECTIVES
}

\author{
Dr MF Cusi, MB, BS, Cert. Sports Med.
}

The use of performance enhancing agents has been present in Olympic sport since the Greek Games, and throughout the modern Olympics." The term "Doping" has been borrowed from the horse racing fraternity. The word derives from Dop, a stimulant used by the Kafirs in Southeast Africa.

Definitions of doping have been based on the ability to detect forbidden substances and practices. ${ }^{234}$ A more philosophical definition, artificial performance enhancing, was proposed by the IOC Medical Commission Chairman.

The IOC has declared war on three accounts:

a) To protect the health of athletes

b) To uphold Sports Ethics, which is contrary to scientific manipulation

c) To ensure fair competition ${ }^{5}$

The official position in Australian sport is quite clear:

"1. Doping is forbidden. The ASC condemns the use of performance enhancing substances as both dangerous and contrary to the ethics of sport. It recognises the need to take strong and positive action to eliminate doping."

The means to implement this policy have been to test for banned drugs and to impose heavy penalties on those found "positive". Education has been advocated, but no clear goals and guidelines have been set. Knowing athletes' motives for drug use could also point to possible solutions.

Much remains unknown in this area. Surveys on the extent of doping are plagued by underreporting. ${ }^{7.8}$ The severe attitude that prevails at present will preclude controlled studies in future. ${ }^{9}$

The interest of doping for a medical practitioner is threefold.

1. Knowledge of drug intake is part of a good medical history.

2. Doctors' attitudes bear important consequences, as athletes regard doctors as reliable sources of information on drugs. ${ }^{10}$ Attitudes can vary from assisting athletes to use drugs, to reporting them to the relevant sporting authorities, or simply ignoring the matter.

3. The extent of doctors' responsibility in advising and prescribing in these matters. These difficult issues will be discussed in the context of three scenarios that medical practitioners may have to face.

\section{SCENARIO 1. THE OFFICIAL TEAM DOCTOR}

May the doctor of a sports team prescribe banned substances?

The answer is simple: Doctors officially involved in competition sport may not ethically prescribe banned substances by virtue of the rules that govern that particular sport. Any exception to the rules must be authorised by the appropriate authorities in advance.

\section{SCENARIO 2. ANABOLIC STEROIDS IN A NON-}

\section{COMPETITIVE ATHLETE}

A young man wants to improve his body image lifting weights, and feels that the anabolic steroids (A.S.) will help him achieve his goal. Competition rules cannot be broken because there is no competition. The doctor needs to ask four questions to decide whether it would be ethical to write a prescription for anabolic steroids.
1. Are Anabolic Steroids Effective?

The scientific literature has been inconsistent and at times at odds with empirical wisdom of the athletic community regarding the ergogenic effects of A.S. However, the answer would have to be YES. 11

2. Are there any contraindications?

The answer is also YES, but we need not consider this point any further in our argument.

3. Are there side effects and how serious are they? The answer is again YES: there are changes in organ function, energy metabolism and also signs of psychological dependence. ${ }^{12}$ Side effects should be compared to potential benefits before making a clinical decision to prescribe.

4. Can we prevent, cure or alleviate a clinical condition with this prescription?

The answer is a definite NO.

Therefore the ethical response to a request of this kind is to decline the prescription. The reaction of the athlete can be either.

a) to accept the advice and not take the A.S.

b) to threaten the doctor with taking low quality black market Steroids "because they were not made available by prescription." There are three possible courses of action open to the medical practitioner who faces this kind of blackmail.

\section{The Damage-Control Approach}

Presented with a "Fait Accompli" some Doctors feel inclined to prescribe the desired drug, in an attempt to prevent patients from taking "street drugs" (with no quality control), and to provide some form of medical monitoring. Maintaining contact with the patient may also give a chance to wean them off for good.

This position is well-intentioned, but flawed for the following reasons:

a) The lesser evil approach is never the right choice. If an action is considered to be wrong, this action should not be taken.

b) There is no guarantee that the athlete will abide by the conditions that the prescriber may set. Anecdotal experience confirms that athletes easily get whatever drugs they want.

c) The prescribing doctor becomes a known source of steroids, and eventually a willing instrument in the spread of their abuse: the very opposite of the original intention.

The Damage-Control Approach is therefore clinically unsound and ethically unwise.

\section{Paternalistic Platitudes}

It is easy to dismiss these athletes with paternalistic platitudes such as "drugs are no good for you". Lack of time or distaste for these matters are not valid reasons for dismissal, because they do not provide the athlete with an answer or a solution to his problem.

\section{Counselling}

Help in these cases requires a mixture of firmness and gentleness in the right dose. Commitment is related to the "bottom line position". I will NOT prescribe A.S. Gentleness refers to the counselling required: simple, logical arguments, to make the potential drug-user think twice. A conversation of this kind may have to cover personal problems, attitudes and misconceptions that the athlete may have about himself and his social 
environment. Counselling is difficult, time-consuming, and often frustrating as the final decision remains with the individual.

\section{SCENARIO 3. A DESPERATE DECISION}

The third scenario involves an elite female shooter. A drop in forms leads to the diagnosis of an essentialfamilial tremor. The treatment of choice is Propranolol, a beta-blocker banned by the IOC.

She wants to perform well at her next meet to secure a long term sponsorship. This puts her in a no-win situation, and her increasing anxiety makes her condition worse. She finally makes a desperate decision: to take Propranolol and give herself a chance to live normally and train as well as she can.

When she talles with her family doctor, a distinction needs to be made between her actions and the actions of the doctor. Both face different ethical decisions. If she competes whilst taking beta-blockers she is in breach of the competition rules.

The prescription of a beta-blocker in this case is good medical practice. In the absence of contraindications it is the drug of choice. The ethical position of the doctor depends on the circumstances:

a) If he is involved in the sport in an official capacity he cannot ethically prescribe a banned drug without official permission, as we saw in Scenario 1.

b) If he is not involved in an official capacity he is not bound by those rules. Thus, provided that he does not approve of rule-breaking and says so, his prescription of the banned drug will be ethical. The primary effect is good: the appropriate treatment of a medical condition.

There is also a bad secondary effect: the doctor will cooperate in the shooter's breach of competition rules if she competes whilst on a banned drug. Both effects are independent of each other: the therapeutic effect is not the result of the doctor's cooperation with the breach of doping regulations.

The proportion between these two effects will determine the ethical legitimacy of the prescription. It is ethical if there is due proportion between the good intended (treatment of a medical condition) and the secondary wrongful effect (cooperation with possible breach of anti-doping regulations).

\section{DISCUSSION}

The three scenarios presented indicate that medical practice is more complex than the IOC's anti-doping rationale admits. Both the rationale and a perceived inconsistency in its application have been criticised in some quarters. A summary of these criticisms would include:

1. The concept of doping being bad per se has not been proved. ${ }^{13}$

2. The ban on drugs for the sake of athlete's health is derived from a paternalistic attitude that denies athletes of the principle of autonomy.

3 . If fair competition means that all athletes can compete on equal terms, most competitions are unfair. Training facilities, coaches, sports physicians and physiology laboratories are not equally available to all athletes.

4. The ban and stigma attached to drugs readily available in everyday medical practice leads athletes to the perception that they can only receive secondclass treatment for a variety of illnesses.

5. The policy of protecting athlete's health will ring hollow as long as boxing continues to be a part of Olympic and Commonwealth Games Programmes. ${ }^{14}$
All the precautions designed to protect boxers only confirm that the purpose of boxing is to punch the opposition to defeat.

As there is some merit in these criticisms, wide and frank debate of these issues is required to provide the IOC with a sound rationale for its ethical stand on doping and for a fair implementation of its policy.

The conflicts that arise need to be addressed both by doctors and sporting authorities, as competitive athletes look to their family doctor as a reliable source of information on drugs. ${ }^{15}$ Four basic points can be highlighted.

1. Doctors who treat athletes need to be aware of doping rules, and to be familiar with the clinical and eth. ical issues involved in the treatment of these patients.

2. The need to maintain independence of one's medical practice. Should there be a conflict of interests, the first loyalty of a treating physician is to the individual patient's welfare above all other considerations. ${ }^{16}$

3. It is important to realise that the patient (athlete) must take the ultimate responsibility for his or her actions, whilst bearing in mind the weight of a doctor's advice.

4. Doping charges often carry strong emotional overtones, which do not help in finding solutions. A good working knowledge of the facts - clinical, historical, personal and ethical - will assist greatly to think clearly, to remain objective and to make fair decisions.

\section{Acknowledgement}

This article was first published in SportHealth (Volume 13 No 1). an official publication of the Australian Sports Medicine Federation Ltd. It is reprinted here with the kind permission of the author and of the editor of SportHealth, Dr Peter Brukner.

\section{REFERENCES}

1. Haynes S., "Doping". ASDA Update. Canberra, 7 May 1991.

2. Haynes S., "Doping". ASDA Update. Canberra, 7 May 1991.

3. Merode A. in "La Vanguardia" (Barcelona, Spain), 3 November 1991.

4. Australian Sports Commission (ASC). "Doping Policy". Canberra. August 1990.

5. Merode A., in "La Vanguardia" (Barcelona, Spain), 3 November 1991.

6. Australian Sports Commission (ASC). "Doping Policy", Canberra. August 1990.

7. Nicholson" A. et al. "Drug use in Sport. A study of the Knowledge and Attitudes of a Section of the Australian Sporting Community". ASDA, 1991.

8. Martin MB and Anshel MK. "Attitudes of elite Australian athletes towards drug Implications for effective drug prevention programmes". Department of Human Movement Science, University of Wollongong, Australia. 1990.

9. Frankle $M$ and Leffers $D$. "Athletes on Anabolic-Androgenic Steroids". The Physician and Sportsmedicine. 20, 6: 75-87. (1992).

10. Martin MB, Anshel MK., op. cit.

11. Yessalis CE, Wright JE and Lombardo JA. "Anabolic-androgenic steroids: a Synthesis of existing data and recommendations for future research" Clinical Sports Medicine 1. 109. 134 (1989).

12. Yessalis CE, Wright JE and Lombardo JA. op. cit.

13. Institute of Medical Ethics. "A Reappraisal". London, October 1987.

14. Australian Medical Association Policies 4/73, 68/90, $69 / 90$.

15. Nicholson A. et al. Op. Cit.

16. World Medicine Association. International code of Ethics. $\square$ 